\title{
Characterization of Void Volume VOC Concentration in Vented TRU Waste Drums-An Interim Report
}

Kevin J. Liekhus

Published September 1994

Idaho National Engineering Laboratory

EG\&G Idaho, Inc.

Idaho Falls, Idaho 83415

Prepared for the

U.S. Department of Energy, Assistant Secretary for

Environmental Restoration and Waste Management

Under DOE Idaho Operations Office

Contract DE-AC07-76ID01570 



\section{DISCLAIMER}

Portions of this document may be illegible in electronic image products. Images are produced from the best available original document. 


\begin{abstract}
A test program is underway at the Idaho National Engineering Laboratory to determine if the concentration of volatile organic compounds (VOCs) in the drum headspace is representative of the VOC concentration in the entire drum void space and to demonstrate that the VOC concentration in the void space of each layer of confinement can be estimated using a model incorporating diffusion and permeation transport principles and limited waste drum sampling data. An experimental test plan was developed requiring gas sampling of 66 transuranic (TRU) waste drums. This interim report summarizes the experimental measurements and model predictions of VOC concentration in the innermost layer of confinement from waste drums sampled and analyzed in FY 1994.
\end{abstract}

\title{
DISCLAIMER
}

This report was prepared as an account of work sponsored by an agency of the United States Government. Neither the United States Government nor any agency thereof, nor any of their employees, makes any warranty, express or implied, or assumes any legal liability or responsibility for the accuracy, completeness, or usefulness of any information, apparatus, product, or process disclosed, or represents that its use would not infringe privately owned rights. Reference herein to any specific commercial product, process, or service by trade name, trademark, manufacturer, or otherwise does not necessarily constitute or imply its endorsement, recommendation, or favoring by the United States Government or any agency thereof. The views and opinions of authors expressed herein do not necessarily state or reflect those of the United States Government or any agency thereof. 


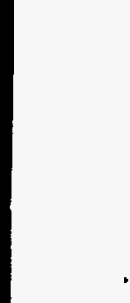




\section{EXECUTIVE SUMMARY}

A test program is underway at the Idaho National Engineering Laboratory to determine if the drum headspace volatile organic compound (VOC) concentration is representative of the entire drum void space as well as to demonstrate that the VOC concentration in the void space of each layer of confinement can be estimated using a model incorporating theoretical diffusion and permeation transport principles and limited waste drum sampling data. The transport model, consisting of a series of material balance equations describing steady-state VOC transport throughout a vented waste drum, was developed to estimate the VOC concentration in the void volumes based on the knowledge of the waste drum configuration and the measured VOC concentration in the drum headspace below the drum filter vent.

A binomial experimental design was proposed to derive a lower bound on the proportion of the time that model estimate of the maximum VOC concentration in a waste drum is equal to or greater than a drum-specific concentration, which is a function of the maximum measured VOC concentration in the waste drum. Gas samples were collected from waste drums containing sludge or solid waste with a maximum of two, four, or five layers of polymer bags. The experimental design requires a total of 66 waste drums to be sampled. Gas samples from sludge waste drums were collected at the Rocky Flats Plant. Gas sampling and waste characterization of drums containing solid waste were performed at the Argonne National Laboratory-West. Drum headspace gas samples were collected by inserting the sample needle through the carbon composite medium of the drum filter vent. The drum and drum liner lids were then removed and gas samples were collected from the innermost drum liner bag headspace and from the headspace of the innermost layer of confinement of all small bags.

Only 30 waste drums have been gas sampled and analyzed to date; therefore, the lower bound of the proportion of the time that the model estimate of the maximum VOC concentration within the innermost layer of confinement equals or exceeds a drum-specific concentration can not be determined at this time. However, a comparison of the model and experimental results does indicate the relative success of the model. Nearly all model results are equal to or greater than the actual concentration in sludge waste drums. In the case of Freon-113, the model results were significantly higher than actual results. Freon-113 permeability in the sludge waste drums appears to be greater than the value assumed in model calculations. A majority of model results for drums containing solid waste were equal to or greater than actual maximum VOC concentration in the innermost layer of confinement. Model calculations were initially performed assuming the smallest estimated surface area as determined from direct examination of the small bags. The minimum small bag surface area in a drum ranged from 800 to $6,500 \mathrm{~cm}^{2}$. Model estimates were also calculated assuming a permeable surface area of $500 \mathrm{~cm}^{2}$. The use of the smaller surface area results in higher, more conservative, estimates of the maximum VOC concentration in the waste drums.

Upon completion of sampling of all waste drums, a final report will be written reporting the proportion of time the model succeeds in generating an estimate that is representative of the VOC concentration in the inner layer of confinement of a vented waste drum. In addition, a position paper will be prepared for the EPA outlining an approach for using VOC transport models to obtain the data required to address the issues of comparability, no-migration determination, and VOC flammability without sampling all layers of confinement. 


i




\section{CONTENTS}

ABSTRACT $\ldots \ldots \ldots \ldots \ldots \ldots \ldots \ldots \ldots \ldots \ldots \ldots \ldots \ldots \ldots \ldots \ldots \ldots \ldots \ldots \ldots \ldots \ldots \ldots$ iii

EXECUTIVE SUMMARY $\ldots \ldots \ldots \ldots \ldots \ldots \ldots \ldots \ldots \ldots \ldots \ldots \ldots \ldots \ldots$

ACRONYMS AND ABBREVIATIONS $\ldots \ldots \ldots \ldots \ldots \ldots \ldots \ldots \ldots \ldots \ldots \ldots \ldots \ldots \ldots$

1. INTRODUCTION $\ldots \ldots \ldots \ldots \ldots \ldots \ldots \ldots \ldots \ldots \ldots \ldots \ldots \ldots \ldots \ldots \ldots$

2. VOC TRANSPORT MODEL $\ldots \ldots \ldots \ldots \ldots \ldots \ldots \ldots \ldots \ldots \ldots \ldots \ldots \ldots \ldots \ldots$

2.1 Model Equations $\ldots \ldots \ldots \ldots \ldots \ldots \ldots \ldots \ldots \ldots \ldots \ldots \ldots \ldots \ldots \ldots \ldots$

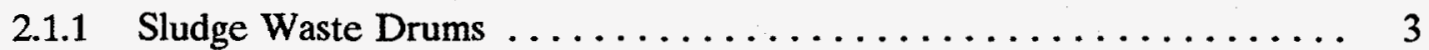

2.1.2 Solid Waste Drums $\ldots \ldots \ldots \ldots \ldots \ldots \ldots \ldots \ldots \ldots \ldots, 4$

$2.2 \quad$ Model Assumptions $\ldots \ldots \ldots \ldots \ldots \ldots \ldots \ldots \ldots \ldots \ldots \ldots \ldots \ldots$

$2.3 \quad$ Model Parameters..$\ldots \ldots \ldots \ldots \ldots \ldots \ldots \ldots \ldots \ldots \ldots \ldots \ldots$

2.3.1 Sludge Waste Drums $\ldots \ldots \ldots \ldots \ldots \ldots \ldots \ldots \ldots \ldots \ldots \ldots \ldots$

2.3.2 Solid Waste Drums $\ldots \ldots \ldots \ldots \ldots \ldots \ldots \ldots \ldots \ldots \ldots, 8$

3. EXPERIMENTAL TEST PLAN $\ldots \ldots \ldots \ldots \ldots \ldots \ldots \ldots \ldots \ldots \ldots, 9$

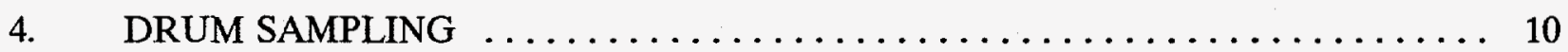

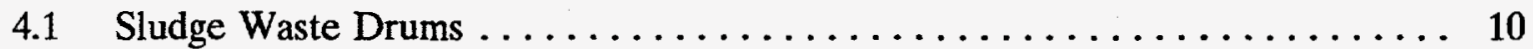

4.2 Solid Waste Drums $\ldots \ldots \ldots \ldots \ldots \ldots \ldots \ldots \ldots \ldots \ldots \ldots \ldots \ldots$

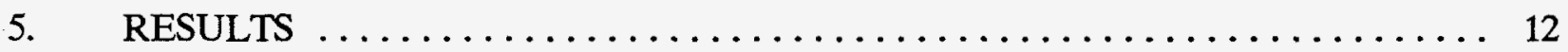

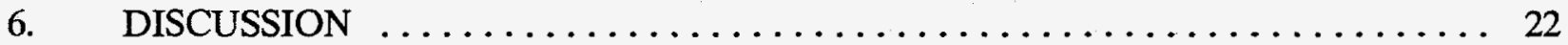

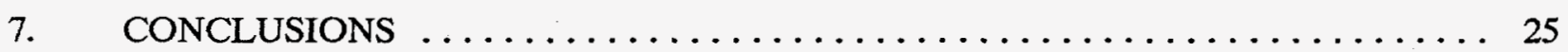

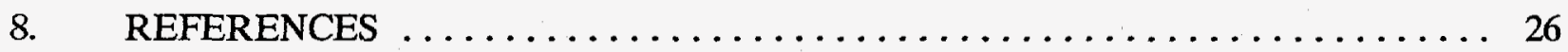

Appendix A-Measured and Estimated VOC Concentrations Inside

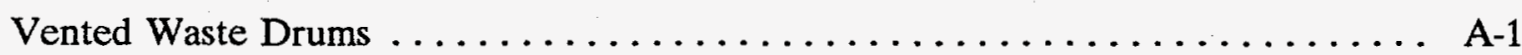

Appendix B-Measured VOC Concentrations Inside Vented

Waste Drums Containing Solid Waste $\ldots \ldots \ldots \ldots \ldots \ldots \ldots \ldots \ldots \ldots \ldots \ldots \ldots \ldots$ 


\section{FIGURES}

1. Possible shapes and dimensions of small bags $\ldots \ldots \ldots \ldots \ldots \ldots \ldots \ldots$

2. Comparison of predicted and measured concentrations of VOCs within innermost layer of confinement in organic sludge drums

3. Comparison of predicted and measured concentrations of VOCs within innermost layer of confinement in inorganic sludge drums

4. Comparison of predicted and measured TCA concentrations in drums containing Waste Types II and III using smallest estimated permeable

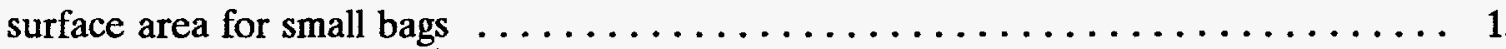

5. Comparison of predicted and measured toluene concentration in drums containing Waste Types II and III using smallest estimated permeable

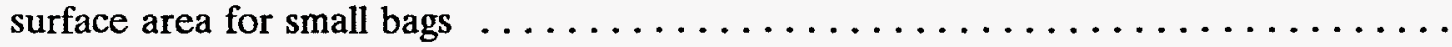

6. Comparison of predicted and measured methylene chloride concentration in drums containing Waste Types II and III using smallest estimated permeable surface area for small bags

7. Comparison of predicted and measured TCA concentrations in drums containing Waste Types II and III assuming a small bag permeable surface area of $500 \mathrm{~cm}^{2}$

8. Comparison of predicted and measured toluene concentrations in drums containing Waste Types II and III assuming a small bag permeable surface area of $500 \mathrm{~cm}^{2}$.

9. Comparison of predicted and measured methylene chloride concentration in drums containing Waste Types II and III assuming a small bag permeable surface area of $500 \mathrm{~cm}^{2}$

\section{TABLES}

A-1. TCA, carbon tetrachloride, and Freon-113 drum headspace concentration (ppm) as well as the measured and predicted concentrations in the innermost layer of confinement in sludge waste drums 
A-2. Drum headspace concentrations (ppm) of other VOCs as well as the measured and predicted concentrations in the innermost layer of confinement in sludge waste drums $\ldots \ldots \ldots \ldots \ldots \ldots \ldots \ldots \ldots \ldots \ldots \ldots \ldots \ldots \ldots . \ldots \ldots$

A-3. The measured VOC drum headspace concentration (ppm), the maximum concentration measured in headspace of polymer bags, and the predicted maximum concentration of TCA, methylene chloride, and toluene in waste drums containing Type II and III waste

A-4. The measured VOC drum headspace concentration (ppm), the maximum VOC concentration measured in polymer bag headspaces, and the predicted maximum concentration of TCE, carbon tetrachloride, methanol, and xylene in waste drums containing Type II and III waste

B-1. Measured VOC concentration and estimated bag surface area in vented waste drum (Drum ID 23664)

B-2. Measured VOC concentration and estimated bag surface area in vented waste drum (Drum ID 22072) . . . . . . . . . . . . . . . . . . . .

B-3. Measured VOC concentration and estimated bag surface area in vented waste drum (Drum ID 22944)

B-4. Measure VOC concentration and estimated surface area in vented waste drum (Drum ID 22312)

B-5. Measure VOC concentration and estimated surface area in vented waste drum (Drum ID 24765)

B-6. Measured VOC concentration and estimated surface area in vented waste drum (Drum ID 22557)

B-7. Measured VOC concentration and estimated bag surface area in vented waste drum (Drum ID 21952) . . . . . . . . . . . . . . . . . .

B-8. Measured VOC concentration and estimated surface area in vented waste drum (Drum ID 24214) $\ldots \ldots \ldots \ldots \ldots \ldots \ldots \ldots \ldots \ldots \ldots \ldots$

B-9. Measured VOC concentration and estimated surface area in vented waste drum (Drum ID 32529) $\ldots \ldots \ldots \ldots \ldots \ldots \ldots \ldots \ldots \ldots \ldots \ldots \ldots$

B-10. Measured VOC concentration and estimated surface area in vented waste drum (Drum ID 10216)

B-11. Measured VOC concentration and estimated bag surface area in vented waste drum (Drum ID 23901) 
B-12. Measured VOC concentration and estimated bag surface area in vented waste drum (Drum ID 24786) $\ldots \ldots \ldots \ldots \ldots \ldots \ldots \ldots \ldots \ldots \ldots \ldots \ldots \ldots \ldots \ldots$

B-13. Measured VOC concentration and estimated bag surface area in vented waste drum (Drum ID 10663)

B-14. Measured VOC concentration and estimated bag surface area in vented waste drum (Drum ID 07170)

B-15. Measured VOC concentration and estimated bag surface area in vented waste drum (Drum ID 08878)

B-16. Measured VOC concentration and estimated bag surface area in vented waste drum (Drum ID 22249)

B-17. Measured VOC concentration and estimated bag surface area in vented waste drum (Drum ID 11433) 


\section{ACRONYMS AND ABBREVIATIONS}

$\begin{array}{ll}\text { ANL-W } & \text { Argonne National Laboratory-West } \\ \text { DOE } & \text { U. S. Department of Energy } \\ \text { EPA } & \text { Environmental Protection Agency } \\ \text { Freon-113 } & \text { 1,1,2-trichloro-1,2,2-trifluoroethane } \\ \text { INEL } & \text { Idaho National Engineering Laboratory } \\ \text { NFT } & \text { Nuclear Filter Technology } \\ \text { NMD } & \text { no-migration determination } \\ \text { PRDL } & \text { program required detection limit } \\ \text { PVC } & \text { polyvinyl chloride } \\ \text { RFP } & \text { Rocky Flats Plant } \\ \text { STP } & \text { standard temperature and pressure } \\ \text { TCA } & \text { trichloroethane } \\ \text { TCE } & \text { trichloroethylene } \\ \text { TRU } & \text { wansuranic } \\ \text { WOC } & \end{array}$




\section{Characterization of Void Volume VOC Concentration in Vented TRU Waste Drums}

\section{INTRODUCTION}

Characterization of transuranic (TRU) waste drums destined for the Waste Isolation Pilot Plant (WIPP) requires detailed characterization of the volatile organic compound (VOC) concentration in the void volume headspaces (drum headspace, the large polymer bag headspace, and the innermost layers of confinement headspace). Extensive sampling is performed to obtain a representative sample from each layer of confinement to identify volatile and gaseous constituents, verify process knowledge of the drum contents, and demonstrate compliance with regulatory requirements. The WIPP conditional no-migration determination (NMD) states that it must be demonstrated that no layer of confinement contains a mixture of gases and VOCs that could become flammable when mixed with air. The NMD also specifies that all layers of confinement in a container will have to be sampled until the U. S. Department of Energy (DOE) can demonstrate to the Environmental Protection Agency (EPA), based on data collected, that sampling of all layers is either unnecessary or can be safely reduced. The DOE must demonstrate to the EPA that a drum headspace sample is representative of the VOCs within the entire void space of the waste container in order to demonstrate compliance in the future when drums could be directly emplaced in the WIPP. A systematic means of describing the VOC concentrations within the innermost layer of confinement, based on the drum headspace concentration, would suggest that the drum headspace sample is representative.

A test program is underway at the Idaho National Engineering Laboratory to determine if the drum headspace VOC concentration is representative of the concentration in the entire drum void space and to demonstrate that the VOC concentration in the void space of each layer of confinement can be estimated using a model incorporating theoretical diffusion and permeation transport principles and limited waste drum sampling data. This interim report presents the application of a model to estimate the VOC concentration within the innermost layer of confinement of a limited number of vented waste drums based on process knowledge and the measured VOC concentration in the drum headspace. 


\section{VOC TRANSPORT MODEL}

A transport model was developed to estimate the VOC concentration in void volumes within a vented drum containing waste contaminated with or containing VOCs. Model parameters are defined from knowledge of the waste drum configuration. A waste drum consists of a vented drum with a rigid drum liner that contains the waste inside one or two large polyethylene bags. The waste may have been placed directly in the innermost large bag or wrapped in one or more layers of smaller polymer bags, which were then placed inside the larger bag. A small opening in the drum liner lid allows gas and vapor transport between the drum liner and drum headspaces. The waste drum configuration includes the type of filter vent in the drum lid, the dimensions of the opening in the drum liner lid, and the thickness of polymer bags surrounding the waste. The model, consisting of a series of material balance equations describing steady-state VOC transport from each distinct void volume in the drum, is presented in this section.

\subsection{Model Equations}

The primary mechanisms for steady-state gas transport across a polymer boundary are permeation across the polymer and diffusion across an opening in the boundary. The steady-state gas transport via permeation across a polymer film is defined as

$r=\left[\frac{\phi \otimes A_{p} P}{x_{p}}\right] c \Delta y_{p}=K_{p} \Delta y_{p}$

where

$$
\begin{aligned}
& \mathbf{r}=\text { gas transport rate, } \mathrm{mol} \mathrm{s}^{-1} \\
& \phi \quad=\quad 76 \mathrm{~T} /(273.15 \mathrm{P}) \\
& \mathrm{T}=\text { temperature, } \mathrm{K} \\
& \mathrm{P} \quad=\quad \text { pressure, } \mathrm{cm} \mathrm{Hg} \\
& \ominus=\text { gas permeability coefficient, } \mathrm{cm}^{3}(\mathrm{STP}) \mathrm{cm} \mathrm{cm}^{-2}(\mathrm{~cm} \mathrm{Hg})^{-1} \mathrm{~s}^{-1} \\
& A_{p}=\text { polymer surface area across which gas permeates, } \mathrm{cm}^{2} \\
& \mathrm{x}_{\mathrm{p}}=\text { polymer boundary thickness, } \mathrm{cm} \\
& \mathrm{c} \quad=\text { total gas concentration }=\mathrm{P}(\mathrm{RT})^{-1}, \mathrm{~mol} \mathrm{~cm}^{-3} \\
& \mathrm{R}=6236.6 \mathrm{~cm}^{3}(\mathrm{~cm} \mathrm{Hg}) \mathrm{mol}^{-1} \mathrm{~K}^{-1} \\
& \Delta y_{p}=\text { gas mole fraction difference across polymer } \\
& \mathrm{K}_{\mathrm{p}}=\text { permeation characteristic, } 4.46 \times 10^{-5} \mathrm{PA}_{\mathrm{p}} \mathrm{Px}_{\mathrm{p}}^{-1}, \mathrm{~mol} \mathrm{~s}^{-1} \text {. }
\end{aligned}
$$


The steady-state gas transport across an opening in polymer boundary layer via gas diffusion is defined as

$r=\left[\frac{D A_{d}}{x_{d}}\right] c \Delta y_{p}=K_{d} \Delta y_{p}$

where

$$
\begin{aligned}
& D=\text { gas diffusivity in air, } \mathrm{cm}^{2} \mathrm{~s}^{-1} \\
& \mathrm{~A}_{\mathrm{d}}=\text { cross-sectional area of opening across polymer boundary, } \mathrm{cm}^{2} \\
& \mathrm{x}_{\mathrm{d}}=\text { diffusional length across opening, } \mathrm{cm} \\
& \mathrm{K}_{\mathrm{d}}=\text { diffusion characteristic, } \mathrm{DA} \mathrm{A}_{\mathrm{d}} \mathrm{P}\left(\mathrm{RTx}_{\mathrm{d}}\right)^{-1}, \mathrm{~mol} \mathrm{~s}^{-1}
\end{aligned}
$$

\subsubsection{Sludge Waste Drums}

The large polymer bag immediately surrounding the sludge waste is the innermost layer of confinement and the headspace surrounding the waste is referred to as the first void volume. Subsequent void volumes are the drum liner headspace not included in the large bags and the drum headspace outside the drum liner, and are numbered accordingly. The VOC transport rate from the innermost layer of confinement, $r$, is defined as

$$
r=K_{p}\left(y_{1}-y_{2}\right)
$$

where

$$
y_{i}=\text { VOC mole fraction in the } i^{\text {th }} \text { void volume. }
$$

The rate of VOC transport from the drum liner is defined as

$$
r=K_{d}\left(y_{2}-y_{3}\right)
$$

The rate of VOC transport from the drum headspace across the filter vent is defined as

$r=D^{*}\left(y_{3}-y_{\infty}\right)$

where

$$
\begin{aligned}
& D^{*}=\text { drum filter vent VOC diffusion characteristic, mol s}{ }^{-1} \\
& y_{\infty}=\text { VOC mole fraction outside waste drum. }
\end{aligned}
$$


The values of $K_{p}$ and $K_{d}$ are calculated based on process knowledge. The VOC mole fraction in the drum headspace, $y_{3}$, is determined from analysis of gas samples collected below the filter vent. Equation (5) is used to define the steady-state VOC transport rate in the waste drum. The VOC mole fraction in the other void volumes are calculated using Equations (3) and (4).

$$
\begin{aligned}
& y_{2}=y_{3}+\frac{r}{K_{d}} \\
& y_{1}=y_{2}+\frac{r}{K_{p}} .
\end{aligned}
$$

\subsubsection{Solid Waste Drums}

Most other waste drums contain waste packaged in one or more layers of small polymer bags. These smaller bags were then placed inside a larger polymer bag. The polymer bag immediately surrounding the waste is the innermost layer of confinement and the headspace inside this layer of confinement is referred to as the first void volume. The headspaces in the large bag, drum liner, and drum are the subsequent void volumes and are numbered accordingly. The VOC transport rate from the innermost layer of confinement is defined by the equation

$$
r=K_{p, 1}\left(y_{1}-y_{2}\right)
$$

where

$$
\mathrm{K}_{\mathrm{p}, 1}=\text { permeation characteristic of first layer of confinement, mol s}{ }^{-1}
$$

The VOC transport across the large polymer bags containing the smaller bags is defined as

$$
r=K_{p, 2}\left(y_{2}-y_{3}\right)
$$

The rate of VOC transport across the drum liner is defined as

$$
r=K_{d}\left(y_{3}-y_{4}\right)
$$

The rate of VOC transport from the drum headspace across the filter vent is defined as

$$
r=D^{*}\left(y_{4}-y_{\infty}\right)
$$

Equation (11) is used to define the steady-state VOC transport rate in the drum. The VOC concentrations in the other void volumes are estimated using Equations (8) through (10). 


$$
\begin{aligned}
& y_{3}=y_{4}+\frac{r}{K_{d}} . \\
& y_{2}=y_{3}+\frac{r}{K_{p, 2}} . \\
& y_{1}=y_{2}+\frac{r}{K_{p, 1}} .
\end{aligned}
$$

\subsection{Model Assumptions}

The following assumptions were made in order to estimate the relationship between the VOC concentration measured in the drum headspace and the VOC concentrations in the other void volumes:

1. An equilibrium exists between the VOC-contaminated waste and the vapor phase in the innermost layer of confinement.

2. The VOC transport rates across all layers of confinement are equal and at steady state.

3. The primary mechanisms for VOC transport are permeation across the polymer bags and diffusion across the drum liner and drum filter vent.

4. A layer of confinement defined by multiple layers of polymer bags is considered a single polymer bag with a bag thickness equal to the sum of the bag thicknesses of the individual bags and a surface area equal to that of the outermost bag.

5. The VOC concentration throughout each void volume is uniform and is zero outside the waste drum.

6. All VOC properties and other model parameters remain constant.

\subsection{Model Parameters}

The VOC permeability coefficients were measured across polyethylene at the INEL using a mixed-component chromatographic detection method. The diffusivities of most VOCs in air at a given temperature and pressure were identified in the literature. ${ }^{1}$ In the case where diffusivity data could not be identified, the VOC diffusivity in air was estimated using the equation ${ }^{2}$ 
$D_{A B}=2.745 \times 10^{-4} \frac{T^{1.823}}{\Pi}\left[p_{c A} p_{c B}\right]^{1 / 3}\left[T_{c A} T_{c B}\right]^{-1 / 2}\left[\frac{1}{M_{A}}+\frac{1}{M_{B}}\right]^{1 / 2}$

where

$$
\begin{aligned}
& \mathrm{D}_{\mathrm{AB}}=\text { mass diffusivity for } \mathrm{VOC}(\mathrm{A}) \text {-air(B) system, } \mathrm{m}^{2} \mathrm{~s}^{-1} \\
& \mathrm{II}=\text { pressure, atm } \\
& \mathrm{p}_{\mathrm{ci}}=\text { critical pressure of species } \mathrm{i} \text {, atm } \\
& \mathrm{T}_{\mathrm{ci}}=\text { critical temperature of species } \mathrm{i}, \mathrm{K} \\
& \mathrm{M}_{\mathrm{i}}=\text { molecular weight of species } \mathrm{i} .
\end{aligned}
$$

The VOC diffusion characteristics across different drum filter vents were measured in experiments performed at EG\&G Idaho. ${ }^{3}$ The effective diffusion length across the liner lid was observed to be greater than the lid thickness when assuming uniform gas concentration in each headspace. ${ }^{4}$

All model parameters, except the small bag surface area, can be estimated from process knowledge prior to characterization of the waste drum contents. During actual waste characterization, the operator estimated the bag shape (rectangular, triangular, elliptical, or cylindrical) of each bag gas sampled and measured the characteristic dimensions of the bag. Each bag shape and its characteristic dimensions are shown in Figure 1. The surface area, $A_{s}$, of a rectangular-shaped bag was calculated using Equation (16)

$$
A_{s}=2[H L+L W+H W]
$$

where $H$ is the bag height, $L$ is the length, and $W$ is the width as shown in Figure 1 . The surface area of a triangular-shaped bag was estimated using Equation (17)

$$
A_{s}=B \sqrt{0.5 W^{2}}+2 \sqrt{\left(H-\frac{W}{2}\right)^{2}+\left(\frac{W}{2}\right)^{2}} \sqrt{0.5 W^{2}+\left(\frac{B}{2}\right)^{2}}
$$

where $B$ is the length of the bag along its base as shown in Figure 1. The surface area of an elliptical-shaped bag was estimated using Equation (18)

$$
A_{s}=1.57\left[W^{2}+\frac{H^{2.25} W^{0.75}}{\sqrt{H^{2}-W^{2}}} \sqrt{1-\frac{W^{2}}{H^{2}}}\right]
$$




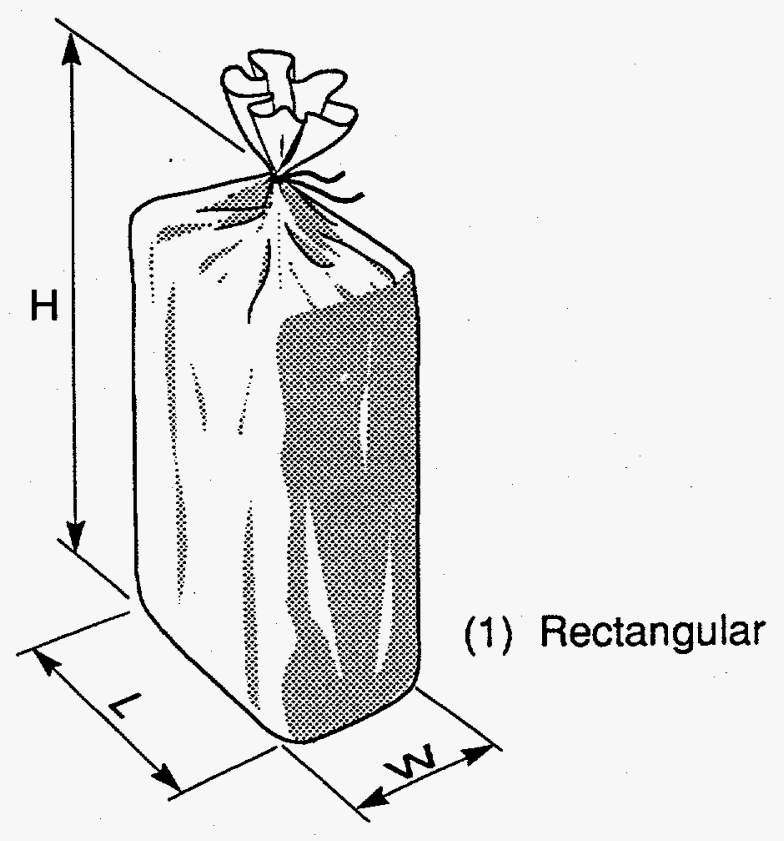

(2) Triangular
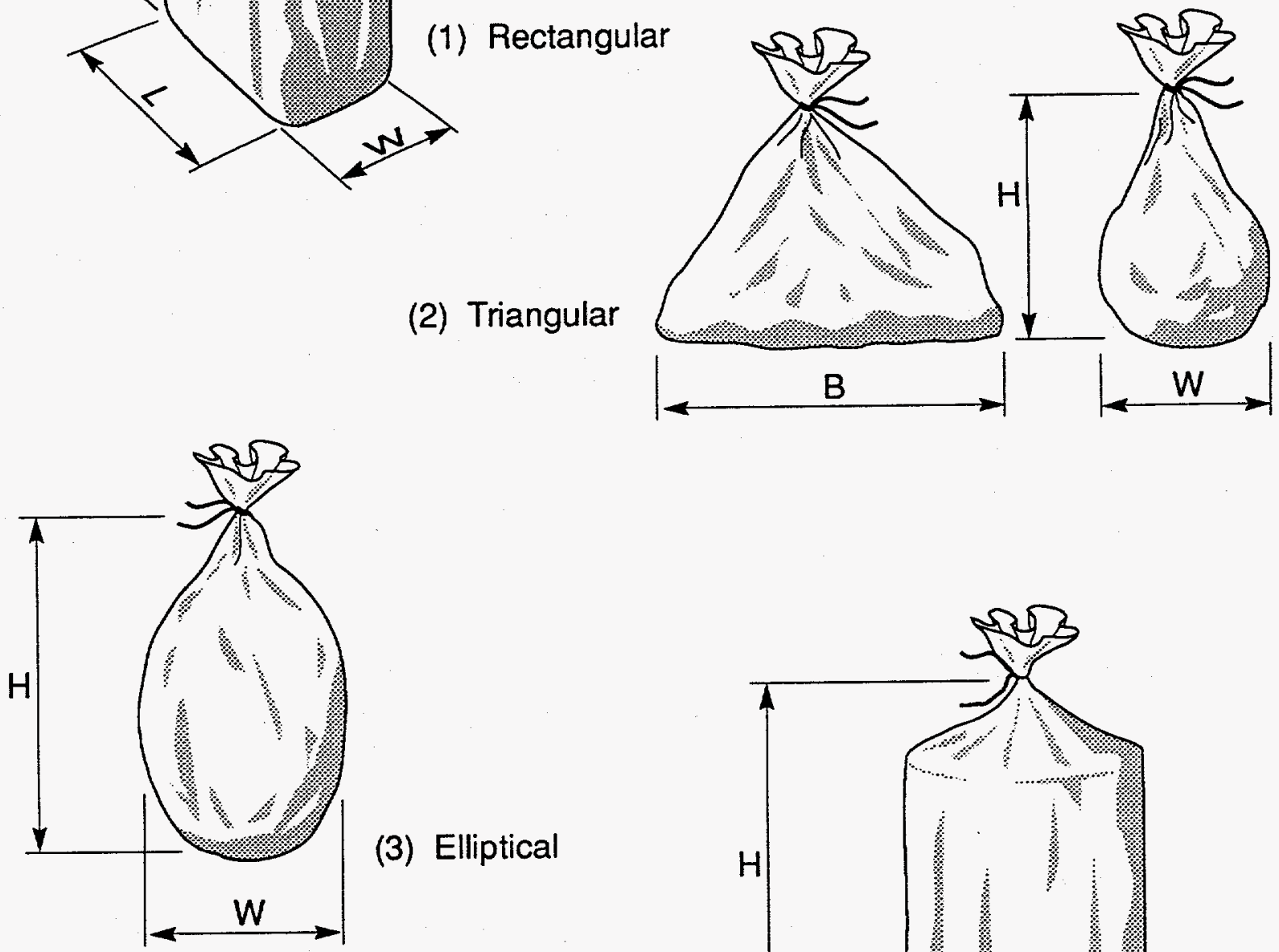

(3) Elliptical

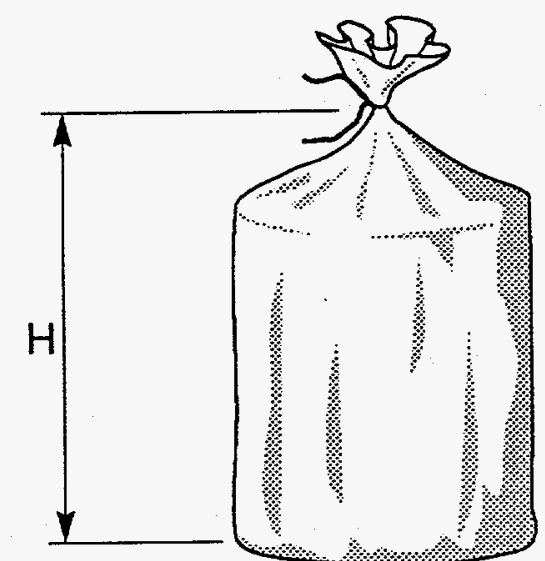

(4) Cylindrical

T93 0071

Figure 1. Possible shapes and dimensions of small bags. 
The surface area of a cylindrical-shaped bag was calculated using Equation (19)

$A_{s}=3.14\left[H D+\frac{D^{2}}{2}\right]$

where is $\mathrm{D}$ is the diameter of the bag as shown in Figure 1.

\subsubsection{Sludge Waste Drums}

Model parameters were measured or estimated from available process knowledge. The bag surface area was estimated to be $2,550 \mathrm{~cm}^{2}$. This corresponds to the cross-sectional area of the drum liner lid. From process knowledge, each polyethylene bag was assumed to be $0.028 \mathrm{~cm}$ (11 mils) thick. The cross-sectional area of the small opening in the drum liner lid is $5.07 \mathrm{~cm}^{2}$. The diffusion length across the drum liner was estimated to be $1.4 \mathrm{~cm} .^{5}$ The measured VOC diffusion characteristics across NFT-012 drum filter vents ranged from $9 \times 10^{-7}$ to $2 \times 10^{-6} \mathrm{~mol} \mathrm{~s}^{-1}$. The waste drums were maintained at ambient room temperature and pressure. When necessary, a temperature of $25^{\circ} \mathrm{C}$ and a pressure of $61.0 \mathrm{~cm} \mathrm{Hg}$ were used in model calculations.

\subsubsection{Solid Waste Drums}

The large bag surface area was estimated to be $2,550 \mathrm{~cm}^{2}$. Each large polyethylene bag was assumed to be $0.028 \mathrm{~cm}$ (11 mils) thick. Small polyethylene bags were assumed to be $0.013 \mathrm{~cm}$ ( 5 mils) thick and polyvinyl chloride (PVC) bags were assumed to be $0.028 \mathrm{~cm}$ (11 mils) thick. If the innermost layer of confinement is a polyethylene bottle, wall thickness of the bottle was assumed to be $0.25 \mathrm{~cm}(100 \mathrm{mils})$. The cross-sectional area of drum liner lid opening is $0.71 \mathrm{~cm}^{2}$. The diffusion length across the drum liner lid was estimated to be $1.2 \mathrm{~cm}$. The measured VOC diffusion characteristics across NFT-020 drum filter vents ranged from $2 \times 10^{-7}$ to $6 \times 10^{-7} \mathrm{~mol} \mathrm{~s}^{-1}$. The waste drums were maintained at ambient room temperature and pressure. When necessary, a temperature of $25^{\circ} \mathrm{C}$ and a pressure of $62.5 \mathrm{~cm} \mathrm{Hg}$ were used in model calculations. 


\section{EXPERIMENTAL TEST PLAN}

A binomial experimental design was initially proposed to derive a lower bound on the proportion of the time that the model estimate of the maximum VOC concentration in a waste drum, $c_{m}$, is greater than the drum-specific concentration, $c_{a}$, which is a function of the maximum VOC concentration measured in the waste drum. One can be $(1-\alpha) 100 \%$ confident that the model value is greater than $c_{a}$ at least $(1-\theta) 100 \%$ of the time if $c_{m}$ is greater than $c_{a}$ for $N$ drums, where $\alpha$ and $\theta$ are some fraction between 0 and 1. For given values of $\alpha$ and $\theta$, the sample size, N, can be estimated

$N=\frac{\log \alpha}{\log (1-\theta)}$.

For the case of $\alpha=0.10$ and $\theta=0.10, \mathrm{~N}$ equals 22 . One could conclude with $90 \%$ confidence that the model will predict a VOC concentration greater than a specified concentration, $c_{a}$, at least $90 \%$ of the time if the model estimate exceeds $c_{a}$ in each of the 22 drums. If model results do not exceed $c_{a}$ for all drums, then a lower confidence bound less than $90 \%$ will be determined. The model effectiveness in estimating VOC concentration was examined for different waste types and configurations. Gas samples were collected from different waste types:

Waste Type I-Solidified aqueous or homogeneous inorganic solids

Waste Type II-Solid inorganics

Waste Type III-Solid organics

Waste Type IV-Solidified organics

The waste drum configuration includes the type of drum filter vent in the filter lid, size of the small opening in the drum liner lid, and the maximum number of layers of plastic bags expected in the waste drum. The waste type and maximum number of layers of plastic bags are identified by the shipping category code. Each shipping code begins with a Roman numeral indicating the waste type. A decimal point and Arabic numeral may follow indicating an effective $G$ value which is only relevant for the issue of hydrogen generation. This is followed by a letter indicating the type of payload container and a number indicating the maximum number of plastic bags in the drum. For example, a shipping category of I.1A4 indicates that the drum contains Waste Type I and no more than four layers of plastic bags around the waste.

The model was tested using waste drums containing all waste types and identified as containing a maximum of two, four, or five layers of polymer bags. The initial design matrix specified 22 Waste Type I drums with a maximum of two layers of plastic bags, 11 drums each of Waste types II and III with a maximum of four layers of plastic bags, and 11 drums each of Waste types II and III with a maximum of five layers of plastic bags. During drum prescreening to identify waste drums with measurable quantities of VOCs, only a few drums of Waste Type I, Waste Type II with five layers of plastic, and Waste Type III with four layers of plastic bags were located. Therefore, the design matrix was adjusted to sample more drums of other waste types so that for a given waste type or maximum number of plastic bags at least 22 drums were sampled. 


\section{DRUM SAMPLING}

Gas samples were collected from sludge waste drums at the Rocky Flats Plant (RFP). Gas sampling and waste characterization of all other waste drums were performed at the Argonne National Laboratory-West (ANL-W). The drum headspace samples were initially collected to identify waste drums with appreciable quantities of VOCs. Drums identified as not having an appreciable VOC concentration were not sampled further.

\subsection{Sludge Waste Drums}

Gas sampling of waste sludge drums was performed in the Rocky Flats Environmental Technology Site Size Reduction Vault airlock. The sampling conducted by the laboratory technicians using a sample cart with SUMMA passivated canisters, vacuum system, and pressure gauge. The gas sampling sequence also included a leak test of the system and a verification of the sampling manifold cleanliness using a photoionization detector. Sample canister cleaning was performed in the analytical laboratory and was verified by gas chromatography/mass spectrometry.

A waste drum consists of a vented drum with a rigid drum liner that contains the waste inside one or two large polyethylene bags. The solidified sludge waste is contained within the innermost large polymer bag. Drum headspace samples were collected by removing the top of the NFT-013 drum filter and inserting a sample needle through the carbon composite medium. After this sample was collected, the drum lid and drum liner lid were removed and a gas sample was collected from the innermost layer of confinement surrounding the waste sludge. The waste sludge was usually contained within two consecutive 55-gallon flat-bottomed polymer drum liner bags. The bag could be made of PVC. The waste drum packaging configuration was documented on data sheets and recorded on videotape. The elapsed time for all samples to be collected from one drum was between 10 and 30 minutes. Drums were not sampled until they had been vented for at least 8 weeks. The data quality objectives outlined in the Quality Assurance Program for the WIPP Experimental-Waste Characterization Program were maintained. ${ }^{6}$

\subsection{Solid Waste Drums}

Gas sampling and visual characterization of stored contact-handled TRU waste drums containing solid waste was performed in the Argonne National Laboratory-West (ANL-W) Hot Fuel Examination Facility Waste Characterization Chamber (WCC). The WCC gas sampling system is a semi-automated process. Operators are responsible for installing a passivated SUMMA canister on the sample manifold and inserting the sample needle in the drum or bag headspace being sampled. The operator activates the computer-controlled process which opens and automatically closes the sample line upon sample collection. Additional tasks automatically performed during the gas sampling sequence include system cleaning with separate helium and air gas streams, validation of system cleanliness using a flame ionization detector, and a leak test of the sampling manifold. If detectable levels of VOCs are found, the cleaning sequence is repeated. The complete gas sampling sequence takes about 20 minutes.

Each waste drum had a drum filter vent in the lid with a rigid drum liner inside. One or two large polyethylene bags inside the drum liner held the solid waste contained within one or more 
Each waste drum had a drum filter vent in the lid with a rigid drum liner inside. One or two large polyethylene bags inside the drum liner held the solid waste contained within one or more layers of smaller polymer bags. A drum headspace sample was collected by inserting the sample needle through the NFT-020 drum filter vent in the drum lid. After gas sample collection, the drum and drum liner lids were removed. A gas sample was collected from the headspace of the innermost layer of the large polymer bags. The top of each large polymer liner bag was then removed to allow the removal of smaller polymer bags. A gas sample from each separate bag was collected from the innermost layer of confinement that was not breached and contained at least $100 \mathrm{~mL}$ of void volume as decided by the operator. An effort was made to conduct the sampling of the drum headspace, the drum liner bag headspace, and the innermost layer of confinement of all small bags in one working day. In some cases, the drum and drum liner bag headspaces were sampled in one day and all small bags were sampled within the next 24 hours. In this case, the drum liner bags were not opened until the second day. Visual characterization consisted of video and audio taping of the gas sampling activities; estimating the bag material and wall thickness; identifying the shape of the bag; measuring the linear dimensions of each bag; and describing the waste contained in the bags. 


\section{RESULTS}

Since all waste drums have not been gas sampled and analyzed, the lower bound of the proportion of the time that the model estimate of the VOC concentration within the innermost layer of confinement equals or exceeds a drum-specific concentration can not be determined at this time. However, a comparison of the model and experimental VOC concentration within the innermost layer can give some indication of the relative success of the model. The predicted and measured VOC concentrations in the waste drums are listed in Appendix A. The measured VOC concentrations within the drum headspace and all polymer bag headspaces in the waste drums containing solid waste are summarized in Appendix B.

The primary constituents observed in the drum headspace of organic sludge waste drums were carbon tetrachloride, 1,1,1-trichloroethane (TCA), and 1,1,2-trichloro-1,2,2-trifluoroethane (Freon-113). In the majority of organic sludge waste drums, the concentration range for carbon tetrachloride was from 1,000 to $100,000 \mathrm{ppm}$; for TCA was from 100 to $100,000 \mathrm{ppm}$; and for Freon-113 was from 100 to $10,000 \mathrm{ppm}$. A comparison of predicted and model results for these VOCs is shown in Figure 2. Five other VOCs (methylene chloride, toluene, $\mathrm{m}$ - and p-xylene, TCE, and methanol) were observed in the sludge waste drums. Analysis for xylenes can not distinguish $\mathrm{m}$-xylene from $\mathrm{p}$-xylene. The concentration range for the majority of these VOC measurements ranged from 1 to $100 \mathrm{ppm}$. The predicted and measured concentrations of these five VOCs in the innermost drum liner bag are shown in Figure 3.

In the waste drums containing Type II and Type III waste, the same VOCs and trichloroethylene (TCE) were observed in at least one drum. Model estimates of the VOC concentration in the innermost layer of confinement were calculated assuming different values for the permeable surface area of the small bags. Calculations were initially performed assuming the smallest estimated surface area as determined from direct examination of the small bags. Comparison of estimated and maximum VOC concentrations for TCA, toluene, and methylene chloride within the innermost layer of confinement are shown in Figures 4, 5, and 6, respectively. For most drums, the concentration ranges for TCA was from $100 \mathrm{ppm}$ to 1,000 ; for toluene was from 10 to $100 \mathrm{ppm}$; and for methylene chloride was from 5 to $50 \mathrm{ppm}$. Comparison of model estimates assuming a permeable surface area of $500 \mathrm{~cm}^{2}$ to measured VOC concentrations are shown in Figures 7 through 9 . The results were plotted graphically because these VOCs were the most common observed. Other VOCs detected in some waste drums but not presented graphically were TCE, methanol, p-xylene, and carbon tetrachloride.

Error bars assigned to each measured concentration was determined using the precision and accuracy data from 30 replicates for each VOC. ${ }^{a}$ In the case where concentrations exceeded the program required detection limit (PRDL), the magnitude of the error bar, e, was calculated as

a. Unpublished research results on WIPP analysis procedures performance data, J. T. Bennett, EG\&G Idaho, Inc. (April 1994). 


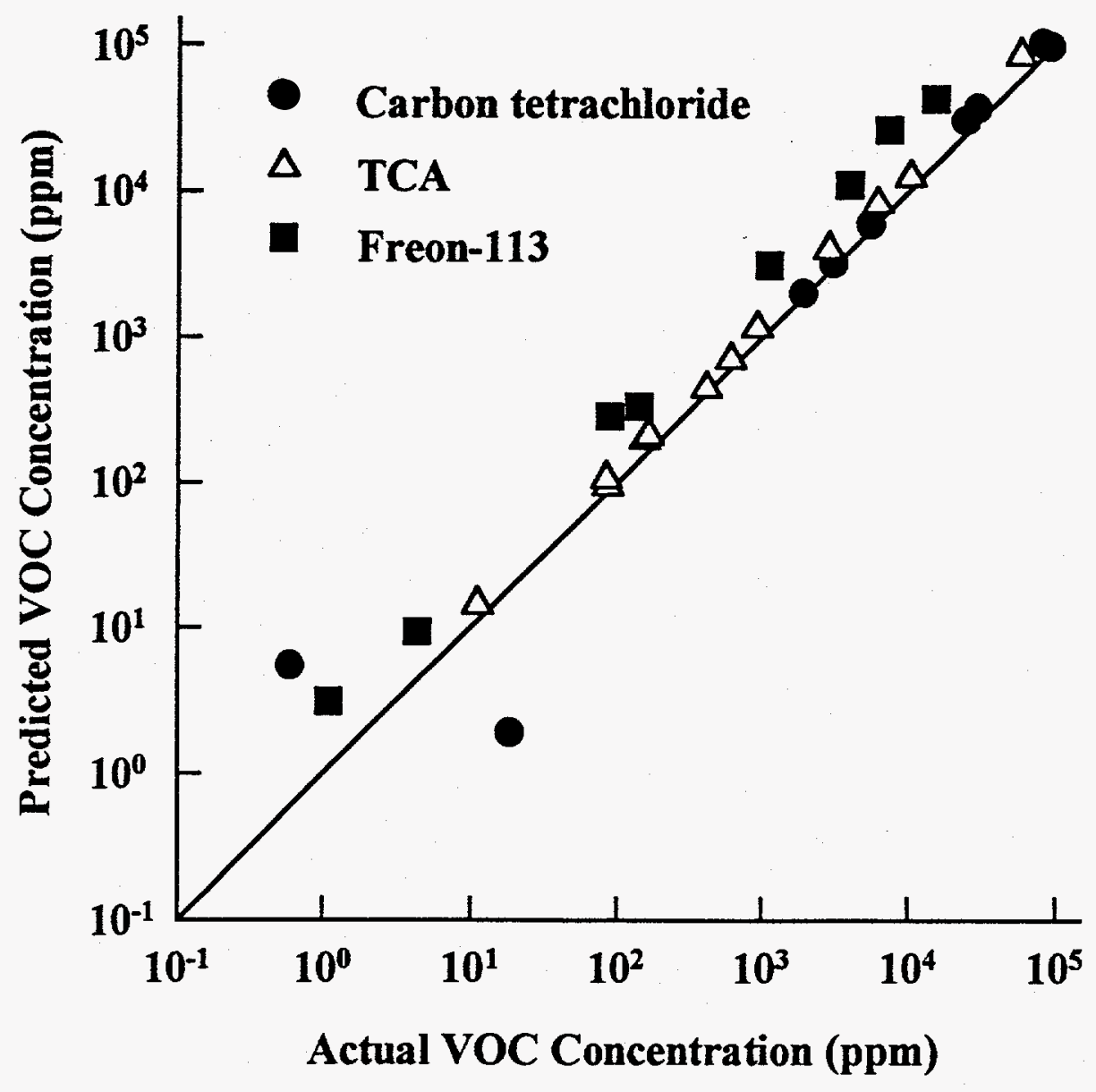

Figure 2. Comparison of predicted and measured concentrations of VOCs within innermost layer of confinement in organic sludge drums. 


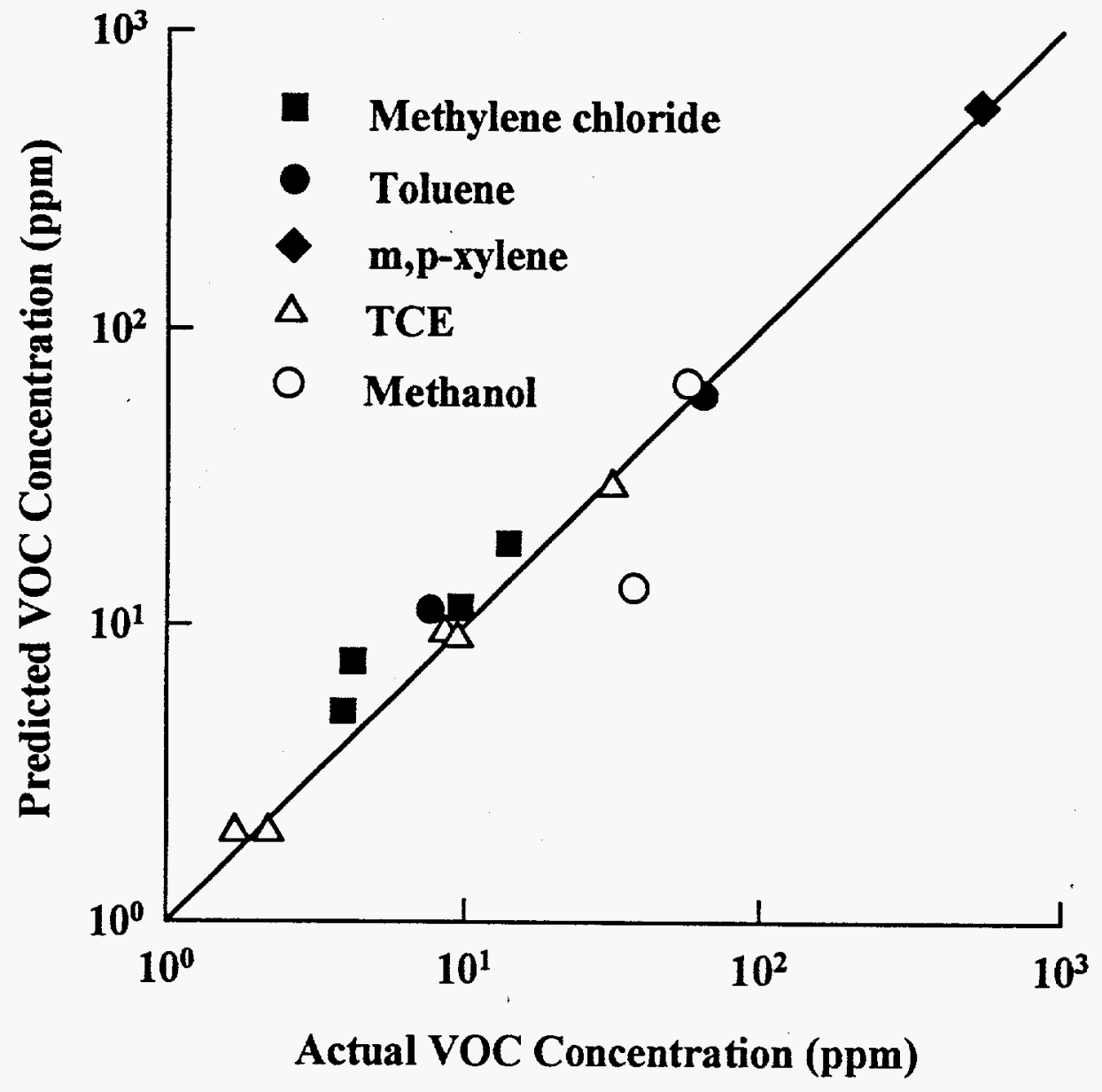

Figure 3. Comparison of predicted and measured concentrations of VOCs within innermost layer of confinement in inorganic sludge drums. 


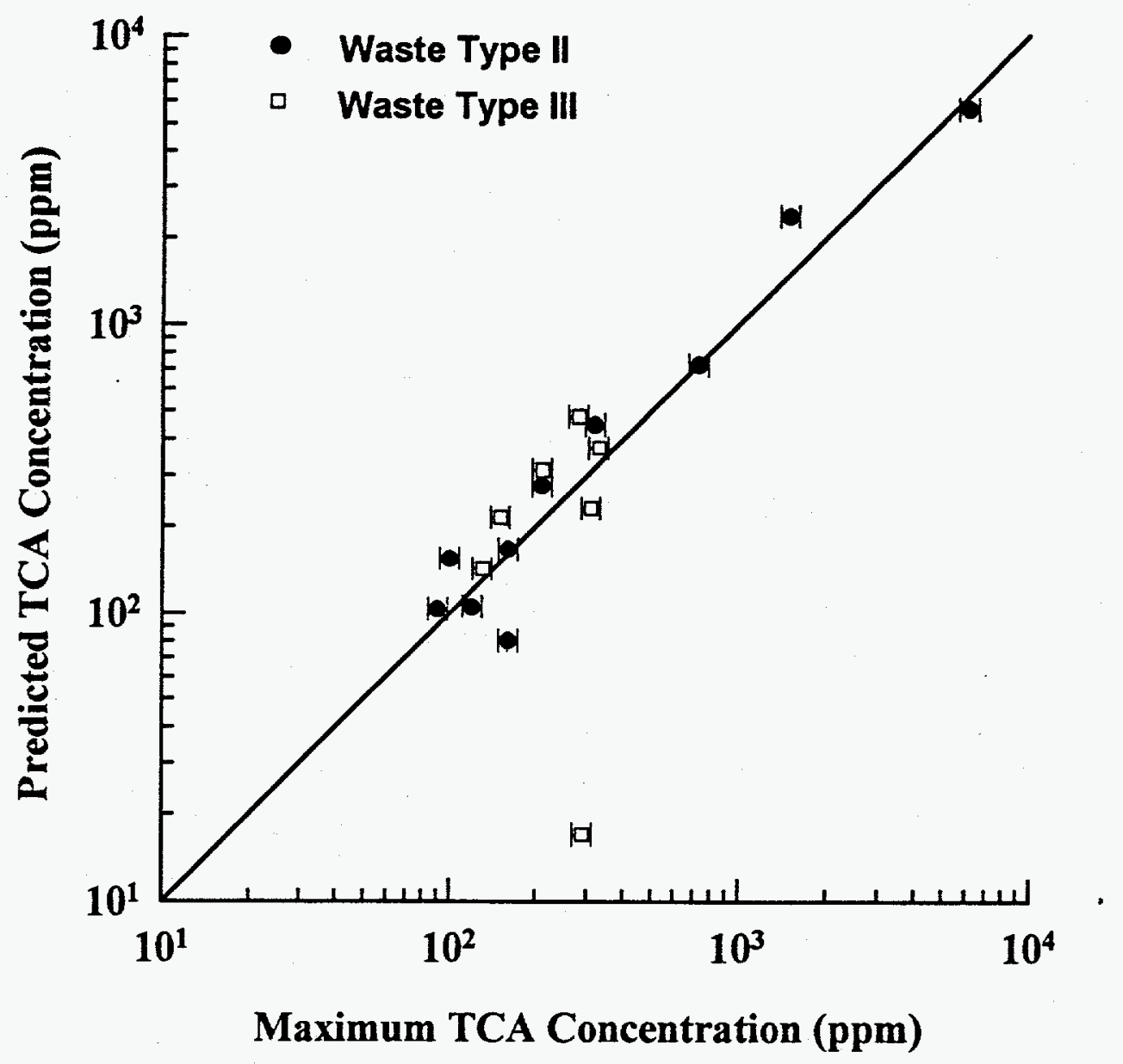

Figure 4. Comparison of predicted and measured TCA concentrations in drums containing Waste Types II and III using smallest estimated permeable surface area for small bags. 


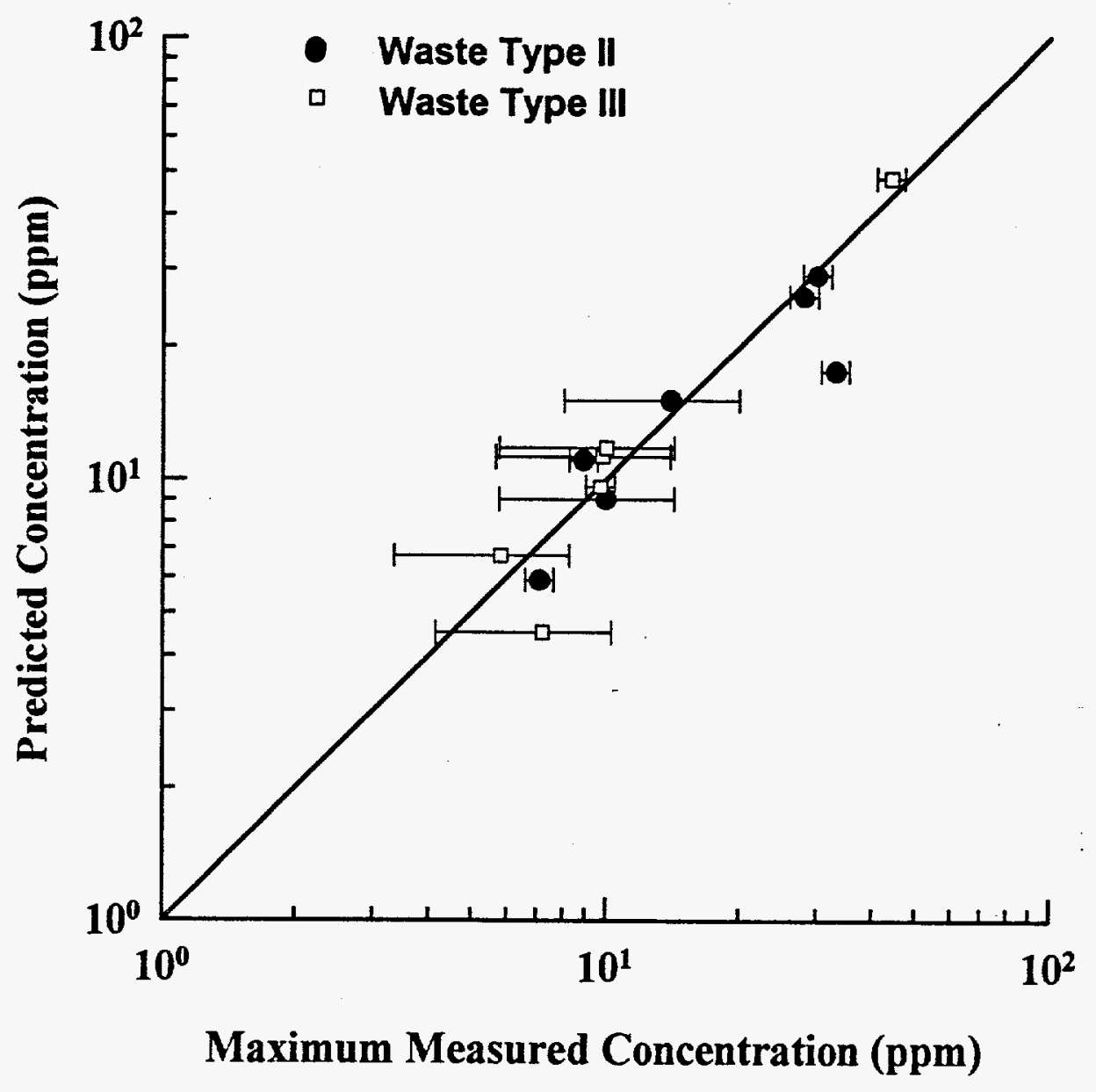

Figure 5. Comparison of predicted and measured toluene concentration in drums containing Waste Types II and III using smallest estimated permeable surface area for small bags. 


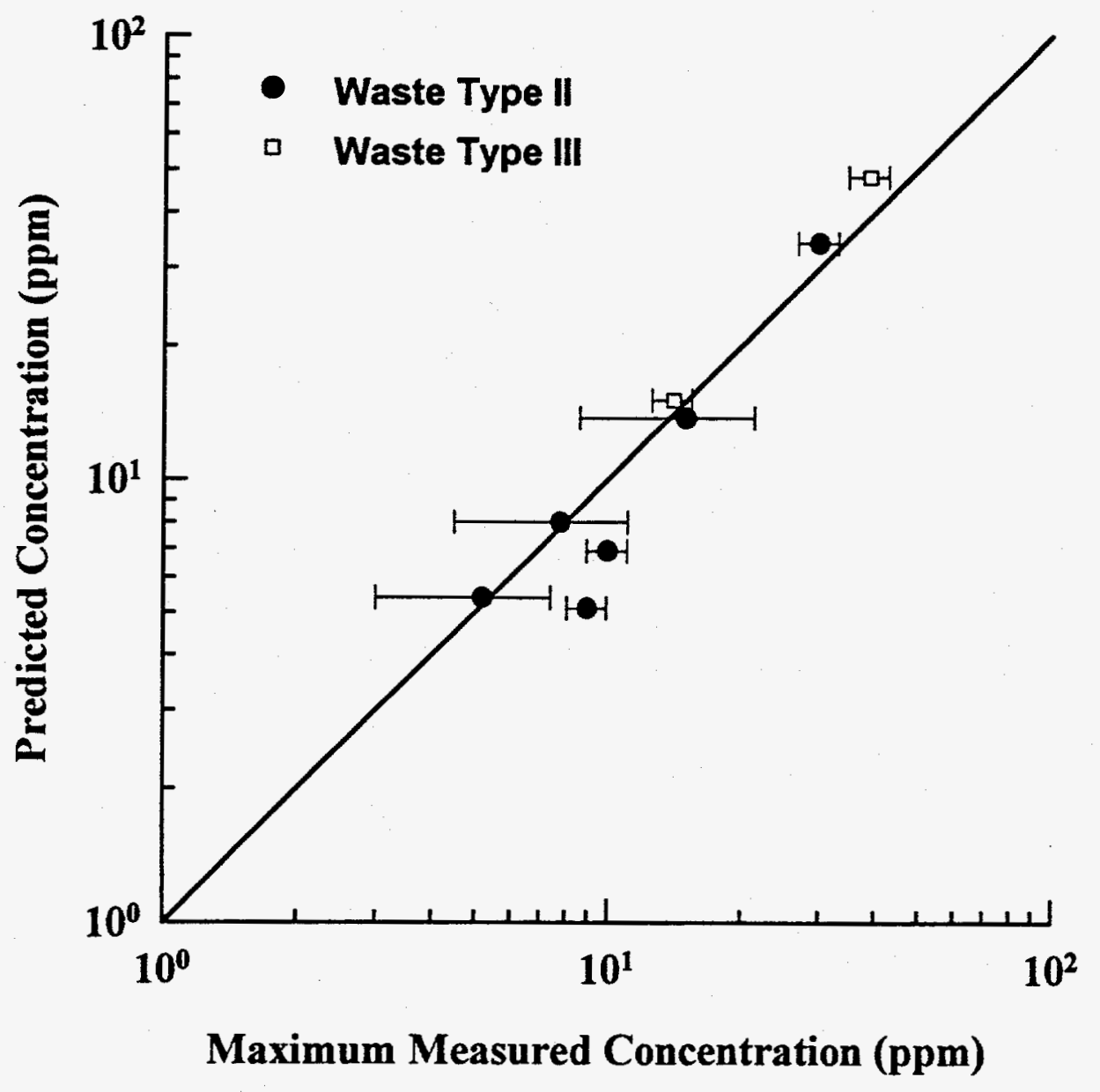

Figure 6. Comparison of predicted and measured methylene chloride concentration in drums containing Waste Types II and III using smallest estimated permeable surface area for small bags. 


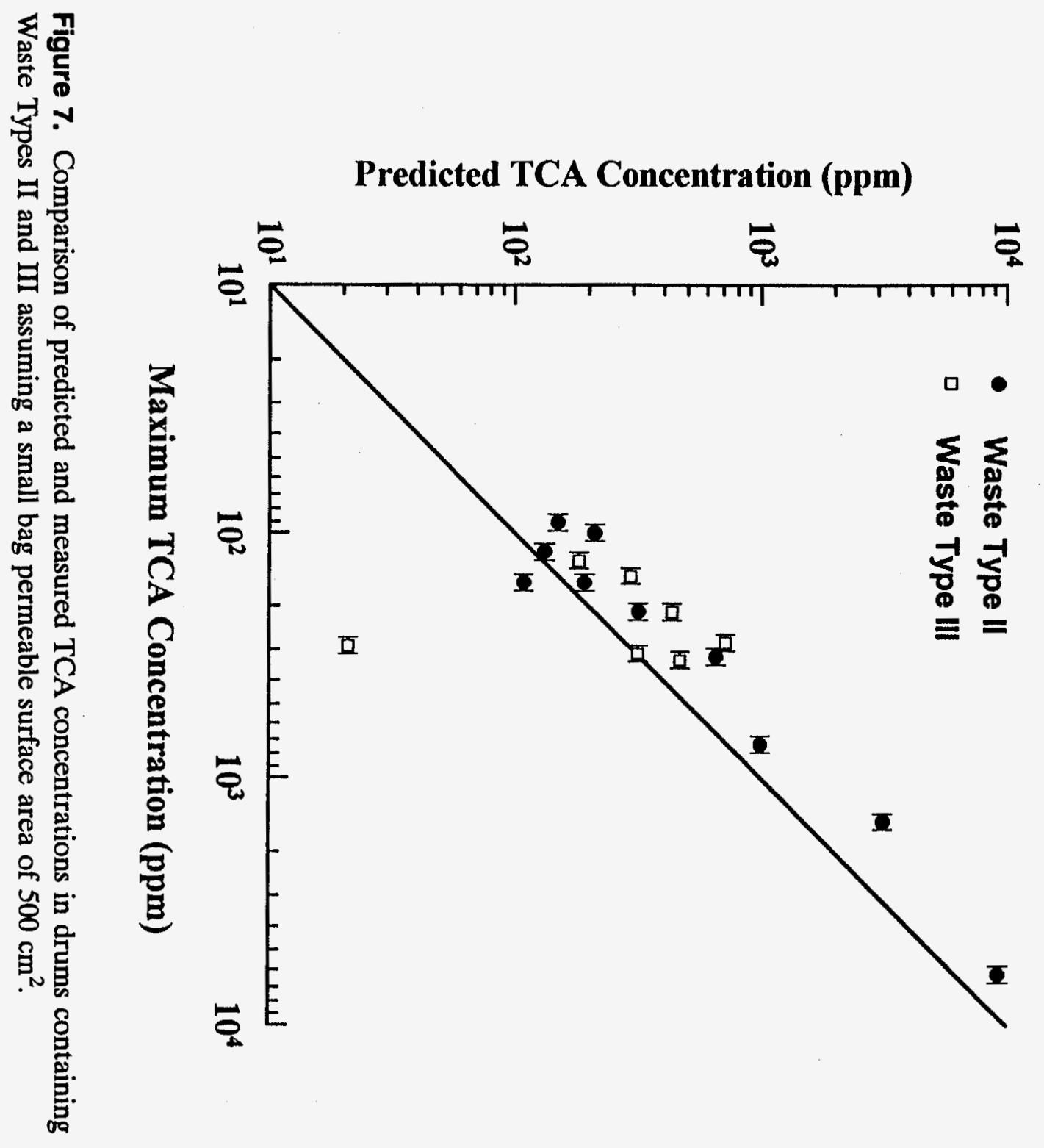




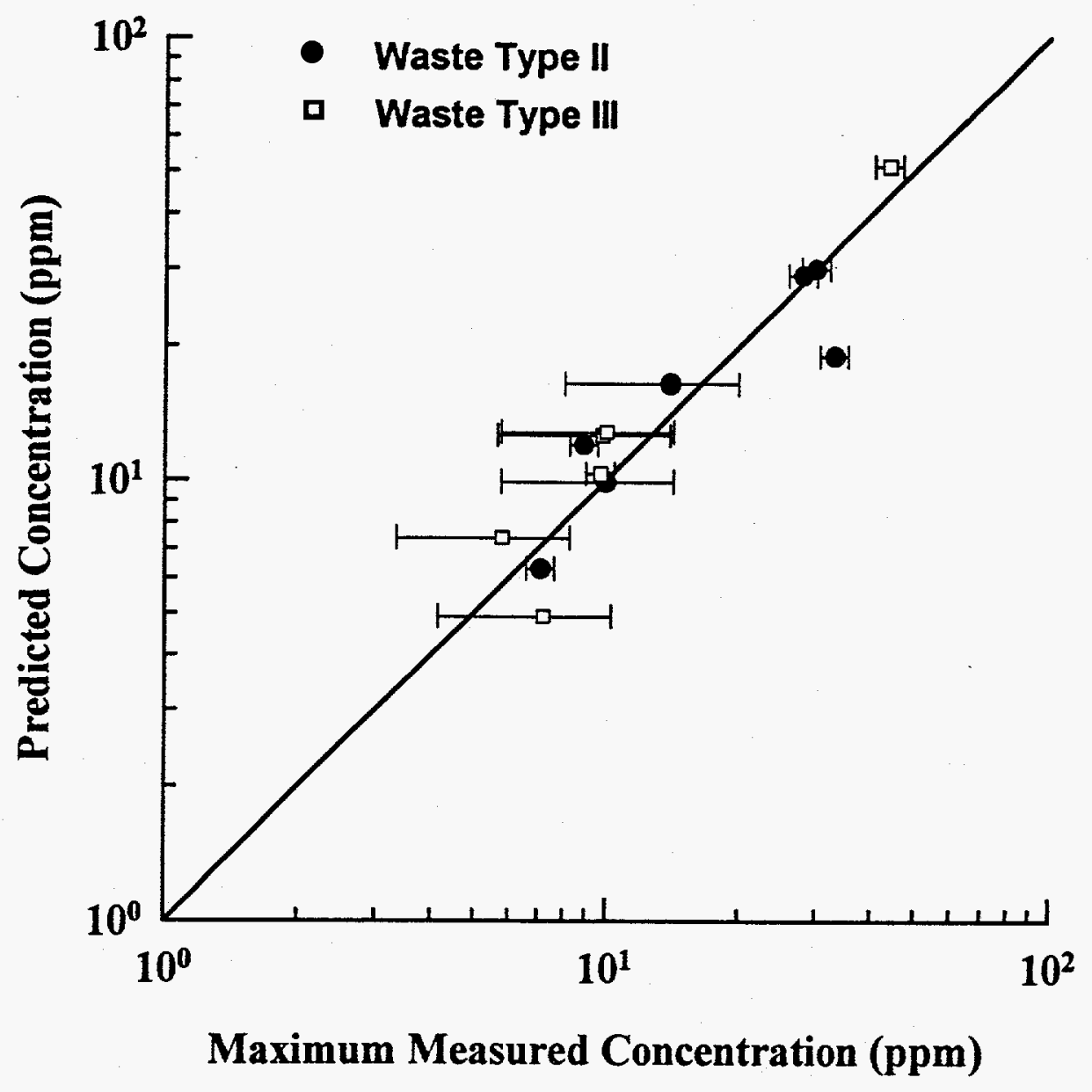

Figure 8. Comparison of predicted and measured toluene concentrations in drums containing Waste Types II and III assuming a small bag permeable surface area of $500 \mathrm{~cm}^{2}$. 


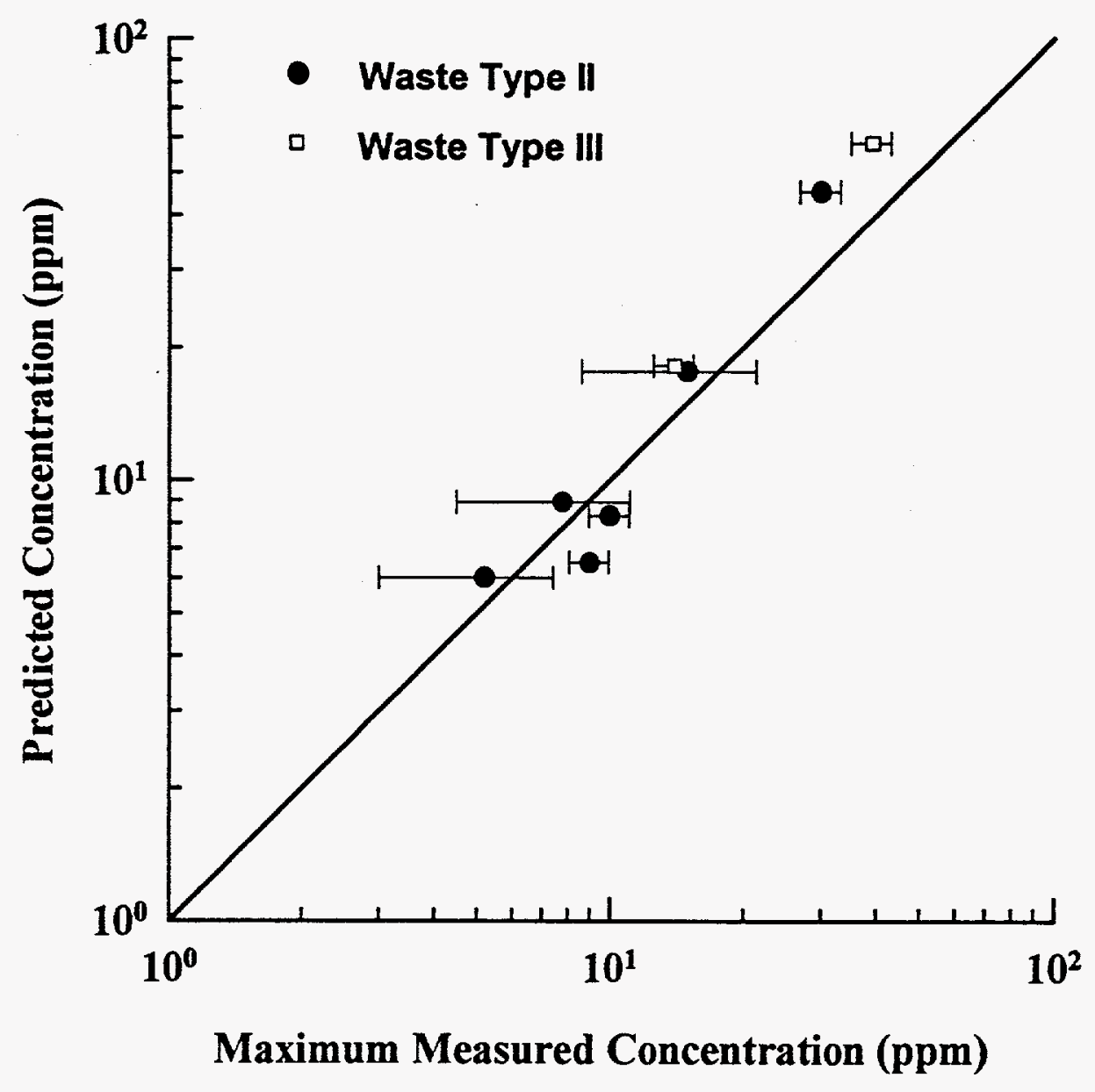

Figure 9. Comparison of predicted and measured methylene chloride concentration in drums containing Waste Types II and III assuming a small bag permeable surface area of $500 \mathrm{~cm}^{2}$. 
$e=\frac{\% R S D}{\% R} t_{0.10,29}$

where

$\%$ RSD percent relative standard deviation

$\% \mathrm{R} \quad$ percent recovery

$\mathrm{t}_{0.1,29} \quad \mathrm{t}$-value at $\alpha=0.10$ and $v=29=1.7$

For most VOCs, $\%$ RSD varied between $5 \%$ and $10 \%$ while percent recovery usually ranged between $90 \%$ to $110 \%$. The ratios of $\% \mathrm{RSD}$ to $\% \mathrm{R}$ for TCA, toluene, and methylene chloride were $0.045,0.043$, and 0.062 , respectively. Error generally increases with decreasing VOC concentration. The precision and accuracy determined from the 30 replicates was assumed to applicable to values exceeding the PRDL. In some cases, VOC concentrations were J-flagged indicating that, while the concentration was greater than or equal to the method detection limit, these values were less than the PRDL. The method detection limit was approximately an order of magnitude less than the PRDL. In these cases, the magnitude of the error bar was determined assuming the maximum allowable \% RSD (25\%) and assuming \% $\mathrm{R}$ of $100 \%$. 


\section{DISCUSSION}

There are currently 29 VOCs that are analyzed for in gas samples collected from all TRU waste drums intended for placement at the WIPP facility. During gas sampling of lab-scale $\mathrm{e}^{3,4}$ and actual waste drums, the accuracy and usefulness of the transport model was determined for nine VOCs that best represented the range of physical properties of all the VOCs. The VOCs cover a range of molecular weights from methanol $(\mathrm{MW}=32)$ to Freon-113 $(\mathrm{MW}=187)$. There are compounds with high permeability across polyethylene (i.e., TCE, toluene) and low permeability (Freon-113). Methanol is a polar compound while carbon tetrachloride is nonpolar. Para-xylene and trichloroethylene exert a low vapor pressure while methylene chloride exerts a high vapor pressure. These VOCs represent the most common compounds observed in actual waste drums.

The comparison of predicted and measured VOC concentrations in the sludge waste drums shows that nearly all model results are equal to or greater than the actual concentration. Thus, the model will provide an accurate, or at least a conservative, estimate of the expected VOC concentration in the drum. Two VOC concentration estimates, out of the over 50 values calculated, were significantly less than actual values. In both cases, the actual VOC concentration was less than $30 \mathrm{ppm}$. In the case of Freon-113, the model results were significantly higher than actual results. This may be an advantageous feature where conservative estimates of VOC concentration are predicted. However, the model is more useful if the estimated values are closer to actual measured values. The significant deviation is indicative that the Freon- 113 permeability used in model calculations may be lower than that in actual waste drums. The effect of VOC interactions and concentration on the permeability across a polymer film was investigated. ${ }^{b}$ Preliminary results show no significant increase in Freon-113 permeability across polyethylene at higher concentrations or when a high concentration of carbon tetrachloride is present. While no change in permeability was observed in these short-term experiments, it is possible that plasticization of the polymer bags is occurring over the long term. Polymer plasticization can result in an increase in VOC permeability across the bag.

During model calculations, VOC permeability across polyethylene was used in all model calculations regardless of the type of polymer bags actually in the drum. All large drum liner bags were polyethylene as were most of the small bags. Only four of the 17 drums contained solid waste inside a PVC bag sealed inside a polyethylene bag. Preliminary test results indicate that VOC permeability across polyethylene is usually equal or greater than across PVC. ${ }^{c}$ A more complex model would allow for the possible presence of PVC and incorporate the VOC permeability across PVC in model calculations. This would introduce another conservative assumption although it is not expected that model results would change significantly. In fact, in the 4 drums containing sealed PVC bags, model results were greater than, less than, or equal to the actual maximum VOC concentration in one drum each. In the case of the fourth drum,

b. Unpublished research results concerning Freon-113 permeability across polyethylene and PVC, E. S. Peterson, EG\&G Idaho, Inc. (September 1994).

c. Unpublished research results of VOC permeability tests across polyethylene and PVC, E. S. Peterson, EG\&G Idaho, Inc. (June 1993). 
model results were nearly 20 times less than the actual VOC concentration suggesting a possible error in gas sampling and analysis of the drum headspace.

A majority of model results for drums containing Waste Types II and III were equal to or greater than actual maximum VOC concentration in the innermost layer of confinement. In most waste drums identified to contain a maximum of five layers of polymer bags, only four layers were observed during waste characterization. One waste drum had measured drum headspace concentration nearly 20 times less than the measured VOC concentration in the innermost layers of confinement. While it is not claimed that the model is absolutely accurate in all cases, the overall success of the model raises the issue whether error in gas sampling and analysis can account for this significant deviation. Errors in the measured VOC concentration will result in either the entry of incorrect input into model equations or inaccurate concentrations associated with the innermost layer of confinement making comparison with model results irrelevant.

The large bag surface area was assumed to be no greater than the cross-sectional area of the drum liner lid. Waste inside the large bag pushes most of the bag surface against the inner drum liner wall. It was assumed that the rest of the large bag was not in direct contact with the gas headspace inside the drum liner. This serves as another conservative assumption. All model parameters except the small bag surface area, could be estimated from process knowledge prior to characterization of the waste drum contents. The estimated small bag surface area ranged from 800 to $6,500 \mathrm{~cm}^{2}$. The smallest estimated surface area of a bag from which a reasonable gas sample was collected was used as the basis for defining the model parameter. The bag with the smallest estimated area did not necessarily contain the highest VOC concentration. The final value was generally rounded down to a value less than the estimated surface area. Waste characterization can identify the range of small bag surface area expected inside waste drums containing different waste types. Direct measurement or estimation of the permeable surface area of the smallest bag is useful, it is still not known across what fraction of the bag that VOC permeation occurs. The use of a bag surface area of $500 \mathrm{~cm}^{2}$ resulted in more conservative estimates of VOC concentrations in the innermost layer of confinement and eliminates the need to determine small bag surface area through direct examination of the waste.

The maximum allowable concentration for flammable VOCs is currently $500 \mathrm{ppm}^{7}$ The lower flammable limit requires a model that is fairly accurate at low concentrations. Model calculations were not performed for VOCs that were reported to be below a specified detection limit. It must be noted that most VOCs listed as undetected in the drum headspace at a specific concentration were not detected at a similar concentration within any other layer of confinement. However in some cases, VOCs were detected within inner layers of confinement although they were not observed in the drum headspace at a specified detection limit. In these cases, the VOC concentrations usually were less than $10 \mathrm{ppm}$ and were reported at a detection level less than the program required detection level. One means to account for this situation is to assume that the VOC concentration in the drum headspace is one-half the detection limit. The risk of this approach is that the cumulative calculated result for 20 flammable VOCs may result in a total greater than the acceptable limit although no flammable VOCs were detected in any headspace. In the case of organic sludges with very high VOC concentrations, some VOCs were listed as undetected at concentrations in excess of $1,000 \mathrm{ppm}$. 
The assumption of uniform VOC concentration in each void volume is made to simplify model calculations. The specification of a diffusion length across the drum liner that is greater than the actual drum thickness is a simple means of accounting for the concentration gradient that exists near the drum liner opening. The effective diffusion length assumed across the drum liner lid only affects the predicted concentration difference across the drum liner. The relative difference decreases as the total VOC concentration in the drum headspace increases. At high VOC concentrations, variability in the permeability coefficient has a greater effect on the estimated concentration than does the effective diffusion length across the drum liner lid. As conditions arise that make the assumptions of uniform VOC concentration more valid, the effective diffusion length will approach the minimum distance separating the two void volumes. The effective diffusion length used in these model calculations was selected because the value resulted in the ratio of predicted VOC concentration in the drum headspace to drum liner headspace of approximately 0.9. A means to better estimate the effective diffusion length is being investigated. 


\section{CONCLUSIONS}

The objective of this study was to determine if the drum headspace VOC concentration is representative of the concentration in the entire drum void space and to demonstrate that the VOC concentration in the void space of each layer of confinement can be estimated using a model incorporating diffusion and permeation transport principles and limited waste drum sampling data. An experimental test plan was developed that required that 66 TRU waste drums be sampled. Although the statistical accuracy of the model in predicting the VOC concentration within the inner layer of confinement can not be determined until all waste drums have been sampled, the following conclusions can be made.

1. Thirty waste drums have been gas sampled and analyzed. For the majority of waste drums, model estimates of VOC concentration within the innermost layer of confinement are equal to or greater than the measured VOC concentration.

2. The maximum permeable surface area of small bags containing Waste Types II and III were estimated to range from 800 to $6,500 \mathrm{~cm}^{2}$. Conservative estimates of the VOC concentration inside a waste drum were calculated assuming a small bag surface area of $500 \mathrm{~cm}^{2}$. This results in higher estimated VOC concentrations but eliminates the problem of determining the minimum bag surface area in each waste drum.

3. Model results indicate that the permeability coefficient of Freon-113 across polyethylene in sludge waste drums may be greater than the value assumed in model calculations.

4. Upon completion of sampling of all waste drums, a final report will be written reporting the proportion of time the model succeeds in generating an estimate that is representative of the VOC concentration in the inner layer of confinement of a vented waste drum. In addition, a position paper will be prepared for the EPA outlining an approach for using VOC transport models to obtain the data required to address the issues of comparability, no-migration determination, and VOC flammability without sampling all layers of confinement. 


\section{REFERENCES}

1. G. A. Lugg, "Diffusion coefficients of some organic and other vapors in air," Analytical Chemistry, 40, 1073 (1968).

2. R. B. Bird, W. E. Stewart, and E. N. Lightfoot, Transport Phenomena, John Wiley: New York, 1960.

3. K. J. Liekhus, Transport Characteristics Across Drum Filter Vents and Polymer Bags, EGG-WM-11454, EG\&G Idaho, Inc., August 1994.

4. K. J. Liekhus, G. L. Gresham, E. S. Peterson, C. Rae, N. J. Hotz, and M. J. Connolly, Modeling Unsteady-state VOC Transport in Simulated Waste Drums, EGG-WM-10823, Rev 1, EG\&G Idaho, Inc., February 1994.

5. K. J. Liekhus, G. L. Gresham, C. Rae, and M. J. Connolly, VOC Transport in Vented Drums Containing Simulated Waste Sludge, EGG-WM-11205, EG\&G Idaho, Inc., February 1994.

6. Quality Assurance Program Plan for the Waste Isolation Pilot Plant Experimental-Waste Characterization Program, Rev. 1, July 1991.

7. Safety Analysis Report for the TRUPACT-II Shipping Package, Rev. 12, Nuclear Packaging, Inc., September 1992. 
Appendix A

Measured and Estimated VOC Concentrations Inside Vented Waste Drums 
Table A-1. TCA, carbon tetrachloride, and Freon-113 drum headspace concentration (ppm) as well as the measured and predicted concentrations in the innermost layer of confinement in sludge waste drums.

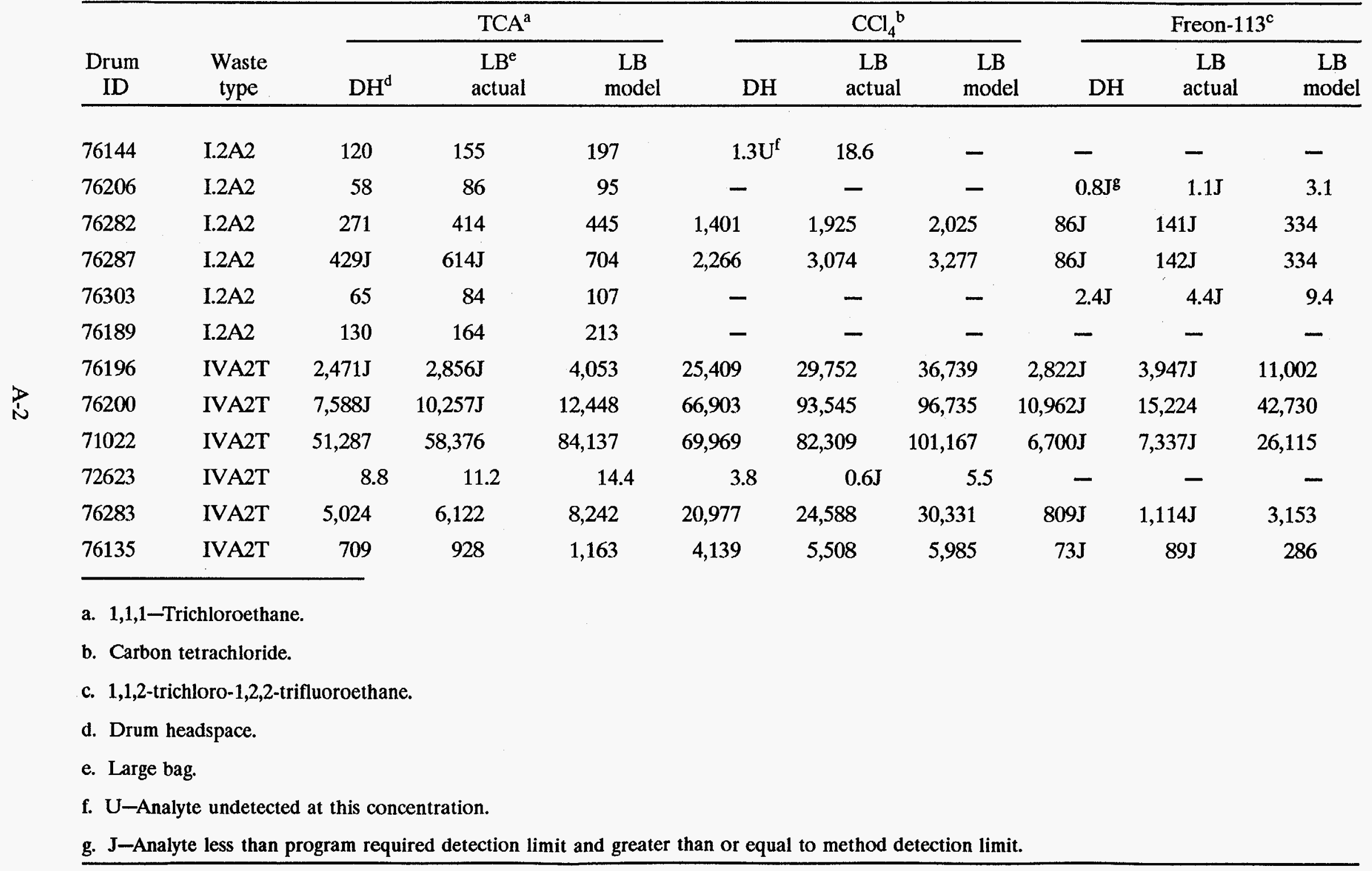


Table A-2. Drum headspace concentrations (ppm) of other VOCs as well as the measured and predicted concentrations in the innermost layer of confinement in sludge waste drums.

\begin{tabular}{|c|c|c|c|c|c|c|c|c|c|c|c|c|c|c|c|c|}
\hline \multirow[b]{2}{*}{$\begin{array}{c}\text { Drum } \\
\text { ID }\end{array}$} & \multirow[b]{2}{*}{$\begin{array}{l}\text { Waste } \\
\text { type }\end{array}$} & \multicolumn{3}{|c|}{$\mathrm{TCE}^{2}$} & \multicolumn{3}{|c|}{$\mathrm{CH}_{2} \mathrm{Cl}_{2}^{\mathrm{b}}$} & \multicolumn{3}{|c|}{ Methanol } & \multicolumn{3}{|c|}{ Toluene } & \multicolumn{3}{|c|}{$\mathrm{m}, \mathrm{p}$-xylene } \\
\hline & & $\mathrm{DH}^{\mathrm{c}}$ & $\begin{array}{c}\mathrm{LB}^{\mathrm{d}} \\
\text { actual }\end{array}$ & $\begin{array}{c}\text { LB } \\
\text { model }\end{array}$ & DH & $\begin{array}{c}\text { LB } \\
\text { actual }\end{array}$ & $\begin{array}{c}\mathrm{LB} \\
\text { model }\end{array}$ & DH & $\begin{array}{c}\mathrm{LB} \\
\text { actual }\end{array}$ & $\begin{array}{c}\text { LB } \\
\text { model }\end{array}$ & DH & $\begin{array}{c}\text { LB } \\
\text { actual }\end{array}$ & $\begin{array}{c}\text { LB } \\
\text { model }\end{array}$ & DH & $\begin{array}{c}\mathrm{LB} \\
\text { actual }\end{array}$ & $\begin{array}{c}\text { LB } \\
\text { model }\end{array}$ \\
\hline 76302 & $\mathrm{I} .2 \mathrm{~A} 2$ & - & - & - & - & - & - & $30 \mathrm{~J}^{\mathrm{e}}$ & $57 \mathrm{~J}$ & 65 & 48 & 64 & 60 & 439 & 558 & 536 \\
\hline 76144 & I. $2 \mathrm{~A} 2$ & - & 8.5 & 9.4 & $3.1 \mathrm{~J}$ & $3.9 \mathrm{~J}$ & 5.1 & - & - & - & - & - & - & - & - & - \\
\hline 76206 & $1.2 \mathrm{~A} 2$ & $1.6 \mathrm{~J}$ & $2.2 \mathrm{~J}$ & 2.0 & 7.0 & 9.6 & 11.4 & - & - & - & - & - & - & - & - & - \\
\hline 76303 & $1.2 \mathrm{~A} 2$ & $1.6 \mathrm{~J}$ & $1.7 \mathrm{~J}$ & 2.0 & $4.6 \mathrm{~J}$ & $4.2 \mathrm{~J}$ & 7.5 & - & - & - & - & - & - & - & - & - \\
\hline 76189 & $1.2 \mathrm{~A} 2$ & $7.3 \mathrm{~J}$ & $9.4 \mathrm{~J}$ & 9.0 & $11.5 \mathrm{~J}$ & $14.0 \mathrm{~J}$ & 18.8 & - & - & - & - & - & - & - & - & - \\
\hline 72623 & IVA2T & 23.7 & 31.5 & 29.3 & - & - & - & $6.1 \mathrm{~J}$ & $38 \mathrm{~J}$ & 13.3 & 9.0 & 7.6 & 11.2 & - & - & - \\
\hline \multicolumn{17}{|c|}{ a. Trichlorethylene. } \\
\hline \multicolumn{17}{|c|}{ b. Methylene chloride. } \\
\hline \multicolumn{17}{|c|}{ c. Drum headspace } \\
\hline d. Larg & ge bag & & & & & & & & & & & & & & & \\
\hline
\end{tabular}


Table A-3. The measured VOC drum headspace concentration ( $\mathrm{ppm}$ ), the maximum concentration measured in headspace of polymer bags, and the predicted maximum concentration of TCA, methylene chloride, and toluene in waste drums containing Type II and III waste.

\begin{tabular}{|c|c|c|c|c|c|c|c|c|c|c|}
\hline \multirow[b]{2}{*}{$\begin{array}{l}\text { Drum } \\
\text { ID }\end{array}$} & \multirow[b]{2}{*}{$\begin{array}{c}\text { Waste } \\
\text { type }\end{array}$} & \multicolumn{3}{|c|}{$\mathrm{TCA}^{\mathrm{a}}$} & \multicolumn{3}{|c|}{$\mathrm{CH}_{2} \mathrm{Cl}_{2}{ }^{\mathrm{b}}$} & \multicolumn{3}{|c|}{ Toluene } \\
\hline & & $\mathrm{DH}^{\mathrm{c}}$ & $\begin{array}{c}\text { Bag } \\
\text { actual }\end{array}$ & $\underset{\text { model }}{\mathrm{Bag}}$ & $\mathrm{DH}$ & $\begin{array}{l}\text { Bag } \\
\text { actual }\end{array}$ & $\underset{\text { model }}{\text { Bag }}$ & DH & $\begin{array}{c}\text { Bag } \\
\text { actual }\end{array}$ & $\underset{\text { model }}{\text { Bag }}$ \\
\hline 23664 & II.1A5 & 310 & 320 & 443 & 25 & 30 & 34 & - & - & - \\
\hline 22072 & II.1A5 & 71 & 91 & 103 & - & - & - & 21 & 28 & 26 \\
\hline 22944 & II.1A5 & 91 & 160 & 166 & $4.9 \mathrm{~J}^{\mathrm{d}}$ & $7.8 \mathrm{~J}$ & 8.0 & - & - & - \\
\hline 22312 & II.1A5 & 470 & 730 & 722 & $9.7 \mathrm{~J}$ & $1.5 \mathrm{~J}$ & 13.7 & $7.2 \mathrm{~J}$ & $10 \mathrm{~J}$ & 9.0 \\
\hline 24765 & II.1A5 & 52 & 160 & 80 & $3.6 \mathrm{~J}$ & 9.0 & 5.1 & 14 & 33 & 18 \\
\hline 22552 & II.1A5 & 150 & 210 & 276 & $3.3 \mathrm{~J}$ & $5.2 \mathrm{~J}$ & 5.4 & 22 & 30 & 29 \\
\hline 21952 & II.1A5 & 100 & 100 & 154 & - & - & - & 8.8 & 8.9 & 11 \\
\hline 22249 & II.1A5 & 1,500 & 1,500 & 2,379 & - & - & - & $12 \mathrm{~J}$ & $14 \mathrm{~J}$ & 15 \\
\hline 08878 & II.1A5 & 1,400 & 6,200 & 5,576 & - & - & - & - & - & - \\
\hline 24786 & II.1AS & 63 & 120 & 105 & $4.6 \mathrm{~J}$ & 10 & 6.9 & $4.6 \mathrm{~J}$ & $7.1 \mathrm{~J}$ & 5.9 \\
\hline 24214 & III.1A4 & 98 & 130 & 142 & 11 & 14 & 15 & 7.8 & 9.7 & 9.6 \\
\hline 32529 & III.1A4 & 250 & 330 & 372 & 35 & 39 & 48 & 39 & 44 & 48 \\
\hline 10216 & III.1A4 & 11 & 290 & 17 & - & - & - & - & - & - \\
\hline 23901 & III.1A5 & 340 & 280 & 478 & - & - & - & $9.2 \mathrm{~J}$ & $9.8 \mathrm{~J}$ & 11 \\
\hline 10663 & III.1A5 & 140 & 150 & 214 & - & - & - & $5.4 \mathrm{~J}$ & $5.8 \mathrm{~J}$ & 6.7 \\
\hline 07170 & III.1A5 & 150 & 310 & 230 & - & - & - & $3.6 \mathrm{~J}$ & $7.2 \mathrm{~J}$ & 4.5 \\
\hline 11433 & III.1A5 & 200 & 210 & 312 & - & - & - & 9.3J & $10 \mathrm{~J}$ & 12 \\
\hline
\end{tabular}

\footnotetext{
a. 1,1,1-Trichloroethane.

b. Carbon Tetrachloride.

c. DH-Drum headspace.

d. J-Analyte less than program required detection limit and greater than or equal to method detection limit.
} 
Table A-4. The measured VOC drum headspace concentration ( $\mathrm{ppm}$ ), the maximum VOC concentration measured in polymer bag headspaces, and the predicted maximum concentration of TCE, carbon tetrachloride, methanol, and xylene in waste drums containing Type II and III waste.

\begin{tabular}{|c|c|c|c|c|c|c|c|c|c|c|c|c|c|}
\hline \multirow[b]{2}{*}{$\begin{array}{l}\text { Drum } \\
\text { ID }\end{array}$} & \multirow[b]{2}{*}{$\begin{array}{c}\text { Waste } \\
\text { type }\end{array}$} & \multicolumn{3}{|c|}{$\mathrm{TCE}^{\mathrm{a}}$} & \multicolumn{3}{|c|}{$\mathrm{CCl}_{4}^{\mathrm{b}}$} & \multicolumn{3}{|c|}{ Methanol } & \multicolumn{3}{|c|}{$\mathrm{m}, \mathrm{p}$-xylene } \\
\hline & & $\mathrm{DH}^{\mathrm{c}}$ & $\begin{array}{c}\text { Bag } \\
\text { actual }\end{array}$ & $\begin{array}{c}\text { Bag } \\
\text { model }\end{array}$ & DH & $\begin{array}{c}\text { Bag } \\
\text { actual }\end{array}$ & $\begin{array}{c}\text { Bag } \\
\text { model }\end{array}$ & $\mathrm{DH}$ & $\begin{array}{c}\text { Bag } \\
\text { actual }\end{array}$ & $\begin{array}{c}\text { Bag } \\
\text { model }\end{array}$ & $\mathrm{DH}$ & $\begin{array}{c}\text { Bag } \\
\text { actual }\end{array}$ & $\begin{array}{c}\text { Bag } \\
\text { model }\end{array}$ \\
\hline 22072 & II.1A5 & 19 & 27 & 22.6 & - & - & - & $180 \mathrm{~J}^{\mathrm{d}}$ & 320 & 394 & - & - & - \\
\hline 24765 & II.1A5 & - & - & - & $0.3 \mathrm{U}^{\mathrm{e}}$ & $1.2 \mathrm{~J}$ & 0.4 & - & - & - & 0.5 & $1.0 \mathrm{~J}$ & 0.6 \\
\hline 22552 & II.1A5 & - & - & - & $1.3 \mathrm{~J}$ & $2.2 \mathrm{~J}$ & 1.9 & - & - & - & - & - & - \\
\hline 21952 & II.1A5 & - & - & - & $0.7 \mathrm{~J}$ & $1.2 \mathrm{~J}$ & 0.9 & - & - & - & - & - & - \\
\hline 24214 & III.1A4 & $2.4 \mathrm{~J}$ & $4.5 \mathrm{~J}$ & 2.9 & - & - & - & - & - & - & 21 & 27 & 25 \\
\hline 10216 & III.1A4 & 39 & 880 & 47 & $0.5 \mathrm{~J}$ & $14 \mathrm{~J}$ & 0.7 & - & - & - & - & - & - \\
\hline 23901 & III.1A5 & 93 & 88 & 110 & - & - & - & - & - & - & - & - & - \\
\hline 10663 & III.1A5 & 210 & 220 & 253 & - & - & - & - & - & - & - & - & - \\
\hline 07170 & III.1A5 & 240 & 490 & 289 & - & - & - & - & - & - & - & - & - \\
\hline 11433 & III.1A5 & 330 & 350 & 399 & $2.0 \mathrm{~J}$ & $2.2 \mathrm{~J}$ & 2.7 & - & - & - & - & - & - \\
\hline
\end{tabular}
a. Trichlorethylene
b. Carbon Tetrachloride
c. DH-Drum headspace
d. J-Analyte less than program required detection limit and greater than or equal to method detection limit
e. U-Analyte undetected at this concentration. 


\section{Appendix B}

\section{Measured VOC Concentrations Inside Vented Waste Drums Containing Solid Waste}


B-2 


\section{Appendix B}

\section{Measured VOC Concentrations Inside Vented Waste Drums Containing Solid Waste}

The VOC concentrations in the drum headspace and the innermost layer of confinement of the large and small polymer bags in vented waste drums containing solid waste sampled and analyzed to date are summarized in the following tables in this Appendix. The waste type is listed for each drum. Waste Type II contains inorganic solid waste and Waste Type III contains primarily organic solid waste. The final Arabic numeral indicates the maximum number of layers of polymer bags expected inside the drum. Waste drums containing the same waste type do not necessarily contain the same waste forms. These waste forms are identified by an INEL identification code (IDC). The IDCs seen in the waste drums sampled so far are summarized below.

$\begin{array}{cll}\text { INEL IDC } & \text { Waste Type } & \text { Description } \\ 330 & \text { III } & \text { Paper and rags - dry } \\ 336 & \text { II } & \text { Paper and rags - moist } \\ 337 & \text { III } & \text { Plastic (Teflon, PVC, etc.) and nonleaded rubber } \\ 338 & \text { III } & \text { Insulation and CWS filter media } \\ 442 & \text { II } & \text { Unleached Raschig rings } \\ 480 & \text { II } & \text { Unleached light non-special source metals }\end{array}$


Table B-1. Measured VOC concentration and estimated bag surface area in vented waste drum (Drum ID 23664).

INEL IDC: 442

Waste type: II.1A5

VOC concentration

\begin{tabular}{|c|c|c|c|c|}
\hline & & & & \\
\hline Canister ID & Layer & $\begin{array}{c}\text { Surface area } \\
\left(\mathrm{cm}^{2}\right)\end{array}$ & $\mathrm{TCA}^{\mathrm{a}}$ & $\mathrm{CH}_{2} \mathrm{Cl}_{2}{ }^{\mathrm{b}}$ \\
\hline EI275 & $\mathrm{DH}^{\mathrm{c}}$ & - & 310 & 25 \\
\hline EI756 & $\mathrm{LB}^{\mathrm{d}}$ & 2,550 & 230 & 20 \\
\hline $\mathrm{EI} 757^{\mathrm{e}}$ & $\mathrm{LB}$ & - & $180 B^{f}$ & $14 \mathrm{~J}^{\mathrm{g}}$ \\
\hline EI759e & LB-D $^{\text {h }}$ & - & $150 \mathrm{~B}$ & $12 \mathrm{~J}$ \\
\hline EI589 & SB-1 ${ }^{i}$ & 6,500 & 280 & 25 \\
\hline $\mathrm{EI} 617^{\mathrm{e}}$ & SB-1D & - & $320 \mathrm{~B}$ & 30 \\
\hline a. 1,1,1-trichloro & & & & \\
\hline b. Methylene chl & & & & \\
\hline c. Drum headspa & & & & \\
\hline d. LB-Large bag. & & & & \\
\hline e. Sample taken & fter DH s & ollected. & & \\
\hline f. B-Analyte dete & ank. & & & \\
\hline $\begin{array}{l}\text { g. J-Analyte less } \\
\text { limit. }\end{array}$ & ram requ & n limit and grea & equal to & detection \\
\hline h. D-Duplicate. & & & & \\
\hline i. SB-Small bag. & & & & \\
\hline
\end{tabular}


Table B-2. Measured VOC concentration and estimated bag surface area in vented waste drum (Drum ID 22072).

INEL IDC: 442

Waste Type: II.1A5

VOC concentration

\begin{tabular}{|c|c|c|c|c|c|c|c|}
\hline Canister ID & Layer & $\begin{array}{l}\text { Surface area } \\
\left(\mathrm{cm}^{2}\right)\end{array}$ & Toluene & $\mathrm{TCA}^{\mathrm{a}}$ & $\mathrm{TCE}^{\mathrm{b}}$ & $\mathrm{MeOH}^{\mathrm{c}}$ & Acetone \\
\hline EI223 & $\mathrm{DH}$ & - & 21 & 71 & 19 & $180 J^{d}$ & $17 \mathrm{U}^{\mathrm{e}}$ \\
\hline EI274 & $D H-D^{\mathfrak{f}}$ & - & 23 & 80 & 21 & $220 \mathrm{~J}$ & $19 \mathrm{~J}$ \\
\hline $\mathrm{EI} 423^{g}$ & $\mathrm{LB}^{\mathrm{h}}$ & 2,550 & 21 & 66 & 18 & 320 & $22 \mathrm{~J}$ \\
\hline EI485g & $S B-1^{i}$ & 5,800 & 28 & 91 & 27 & $220 \mathrm{~J}$ & $24 \mathrm{~J}$ \\
\hline $\mathrm{EI} 468^{g}$ & SB-2 & 5,800 & 25 & $85 \mathrm{~B}^{\mathrm{j}}$ & 23 & $220 \mathrm{~J}$ & $24 \mathrm{~J}$ \\
\hline
\end{tabular}

a. 1,1,1-trichloroethane.

b. Trichloroethylene.

c. Methanol.

d. J-Analyte less than program required detection limit and greater than or equal to method detection limit.

e. U-Analyte undetected at this concentration.

f. D-Duplicate.

g. Samples taken one day after DH sample was collected.

h. LB-Large bag.

i. SB-Small bag.

j. B-Analyte detected in the blank. 
Table B-3. Measured VOC concentration and estimated bag surface area in vented waste drum (Drum ID 22944).

\begin{tabular}{|c|c|c|c|c|}
\hline \multirow{2}{*}{\multicolumn{2}{|c|}{ Waste type: II.1A5 }} & \multicolumn{3}{|c|}{ INEL IDC: 480} \\
\hline & & \multicolumn{3}{|c|}{$\begin{array}{l}\text { VOC concentration } \\
\text { (ppm) }\end{array}$} \\
\hline Canister ID & Layer & $\begin{array}{l}\text { Surface area } \\
\left(\mathrm{cm}^{2}\right)\end{array}$ & $\mathrm{TCA}^{\mathrm{a}}$ & $\mathrm{CH}_{2} \mathrm{Cl}_{2}{ }^{\mathrm{b}}$ \\
\hline $\mathrm{EI} 772$ & $\mathrm{DH}^{\mathrm{c}}$ & - & 91 & $4.9 \mathrm{~J}^{\mathrm{d}}$ \\
\hline EI782 & $\mathrm{LB}^{\mathrm{e}}$ & 2,550 & 80 & $4.3 \mathrm{~J}$ \\
\hline EI620 & SB-1 ${ }^{\mathrm{f}}$ & 1,700 & 160 & $7.8 \mathrm{~J}$ \\
\hline EI754 & SB-2 & 870 & 92 & $4.5 \mathrm{~J}$ \\
\hline EI774 & SB-3 & 960 & 110 & $5.7 \mathrm{~J}$ \\
\hline $\mathrm{EI} 290^{\mathrm{g}}$ & SB-4 & 2,590 & $0.55 \mathrm{~J}$ & $0.1 \mathrm{U}^{\mathrm{h}}$ \\
\hline EI054 & SB-5 & 540 & 20 & $0.6 \mathrm{~J}$ \\
\hline EI830 & SB-6 & 1,400 & 58 & $2.4 \mathrm{~J}$ \\
\hline \multicolumn{5}{|c|}{ a. 1,1,1-trichloroethane. } \\
\hline \multicolumn{5}{|c|}{ b. Methylene chloride. } \\
\hline \multicolumn{5}{|c|}{ c. Drum headspace. } \\
\hline \multicolumn{5}{|c|}{$\begin{array}{l}\text { d. J-Analyte less than program required detection limit and greater than or equal to method detection } \\
\text { limit. }\end{array}$} \\
\hline \multicolumn{5}{|c|}{ e. LB-Large bag. } \\
\hline \multicolumn{5}{|c|}{ f. SB-Small bag. } \\
\hline \multicolumn{5}{|c|}{ g. $100 \mathrm{~mL}$ sample collected from innermost layer of confinement. } \\
\hline h. U-Analyte & is con & & & \\
\hline
\end{tabular}


Table B-4. Measure VOC concentration and estimated surface area in vented waste drum (Drum ID 22312).

INEL IDC: 480

Waste Type: II.1A5

VOC concentration

\begin{tabular}{llccccc}
\hline Canister ID & Layer & $\begin{array}{c}\text { Surface area } \\
\left(\mathrm{cm}^{2}\right)\end{array}$ & Toluene & $\mathrm{TCA}^{\mathrm{a}}$ & $\mathrm{CH}_{2} \mathrm{Cl}_{2}{ }^{\mathrm{b}}$ & Acetone \\
\hline EI473 & DH $^{\mathrm{c}}$ & - & $7.2 \mathrm{~J}^{\mathrm{d}}$ & 470 & $9.7 \mathrm{~J}$ & $46 \mathrm{~J}$ \\
EI470 & LB $^{\mathrm{e}}$ & 2,550 & $11 . \mathrm{J}$ & 680 & $15 \mathrm{~J}$ & $72 \mathrm{~J}$ \\
EI475 $^{\mathrm{f}}$ & SB-1 $^{\mathrm{g}}$ & 3,070 & $8.9 \mathrm{~J}$ & 730 & $15 \mathrm{~J}$ & $63 \mathrm{~J}$ \\
EI482 $^{\mathrm{f}}$ & SB-2 & 2,650 & $8.0 \mathrm{~J}$ & 600 & $14 \mathrm{~J}$ & $65 \mathrm{~J}$ \\
EI474 $^{\mathrm{f}}$ & SB-3 & 3,160 & $10 . \mathrm{J}$ & 630 & $14 \mathrm{~J}$ & $66 \mathrm{~J}$ \\
EI483 $^{\mathrm{f}}$ & SB-4 & 3,800 & $9.1 \mathrm{~J}$ & 670 & $14 \mathrm{~J}$ & $80 \mathrm{~J}$ \\
EI467 $^{\mathrm{f}}$ & SB-5 & 4,220 & $9.9 \mathrm{~J}$ & 570 & $13 \mathrm{~J}$ & $51 \mathrm{~J}$ \\
EI524 $^{\mathrm{f}}$ & SB-6 & 2,720 & $8.8 \mathrm{~J}$ & 640 & $12 \mathrm{~J}$ & $65 \mathrm{~J}$
\end{tabular}
a. 1,1,1-trichloroethane.
b. Methylene chloride.
c. Drum headspace.

d. J-Analyte less than program required detection limit and greater than or equal to method detection limit.

e. LB-Large bag.

f. Samples taken one day after DH sample was collected.

g. SB-Small bag. 
Table B-5. Measure VOC concentration and estimated surface area in vented waste drum (Drum ID 24765).

INEL IDC: 480

\begin{tabular}{|c|c|c|c|c|c|c|c|}
\hline \multirow{2}{*}{\multicolumn{2}{|c|}{ Waste Type: II.1A5 }} & \multicolumn{6}{|c|}{ INEL IDC: 480} \\
\hline & & \multicolumn{6}{|c|}{$\begin{array}{l}\text { VOC concentration } \\
\qquad(\mathrm{ppm})\end{array}$} \\
\hline Canister ID & Layer & $\begin{array}{l}\text { Surface area } \\
\left(\mathrm{cm}^{2}\right)\end{array}$ & Toluene & Xylene $^{\mathbf{a}}$ & $\mathrm{TCA}^{\mathrm{b}}$ & $\mathrm{CCl}_{4}{ }^{\mathrm{c}}$ & $\mathrm{CH}_{2} \mathrm{Cl}_{2}^{\mathrm{d}}$ \\
\hline EI768 & $\mathrm{DH}^{\mathrm{e}}$ & - & 14 & $0.5 \mathrm{~J}^{\mathrm{f}}$ & 52 & $0.3 U^{g}$ & $3.6 \mathrm{~J}$ \\
\hline EI859 & $\mathrm{LB}^{\mathrm{h}}$ & - & 33 & $0.9 \mathrm{~J}$ & 130 & - & 9.0 \\
\hline EI857 & LB-D ${ }^{i}$ & 2,550 & 32 & $1.0 \mathrm{~J}$ & 120 & 一 & 8.5 \\
\hline $\mathrm{EI} 527^{\mathrm{j}}$ & $\mathrm{SB}-1^{\mathrm{k}}$ & 3,880 & 25 & $0.8 \mathrm{~J}$ & 110 & - & 8.2 \\
\hline EI819 & SB-2 & 4,350 & 30 & $1.0 \mathrm{~J}$ & 160 & $1.2 \mathrm{~J}$ & $8.5 \mathrm{~J}$ \\
\hline $\mathrm{EI} 497^{\mathrm{j}}$ & SB-3 & 6,770 & 25 & $0.7 \mathrm{U}$ & 110 & - & $7.2 \mathrm{~J}$ \\
\hline $\mathrm{EI} 765^{\mathrm{j}}$ & SB-4 & 4,330 & 21 & $0.7 \mathrm{~J}$ & 76 & - & 5.7 \\
\hline $\mathrm{EI} 751^{\mathrm{j}}$ & SB-5 & 2,630 & 24 & $0.9 \mathrm{~J}$ & 97 & - & $5.9 \mathrm{~J}$ \\
\hline EI452, & SB-6 & 1,530 & $0.5 \mathrm{~J}$ & $0.1 \mathrm{U}$ & 6.9 & - & $0.8 \mathrm{~J}$ \\
\hline
\end{tabular}
a. m-, p-xylene.
b. 1,1,1-trichloroethane.
c. Carbon tetrachloride.
d. Methylene chloride.
e. Drum headspace.

f. J-Analyte less than program required detection limit and greater than or equal to method detection limit.

g. U-Analyte undetected at this concentration.

h. LB-Large bag.

i. D-Duplicate.

j. Samples taken one day after DH sample was collected.

k. SB-Small bag.

1. $100 \mathrm{ml}$ sample collected. 
Table B-6. Measured VOC concentration and estimated surface area in vented waste drum (Drum ID 22557).

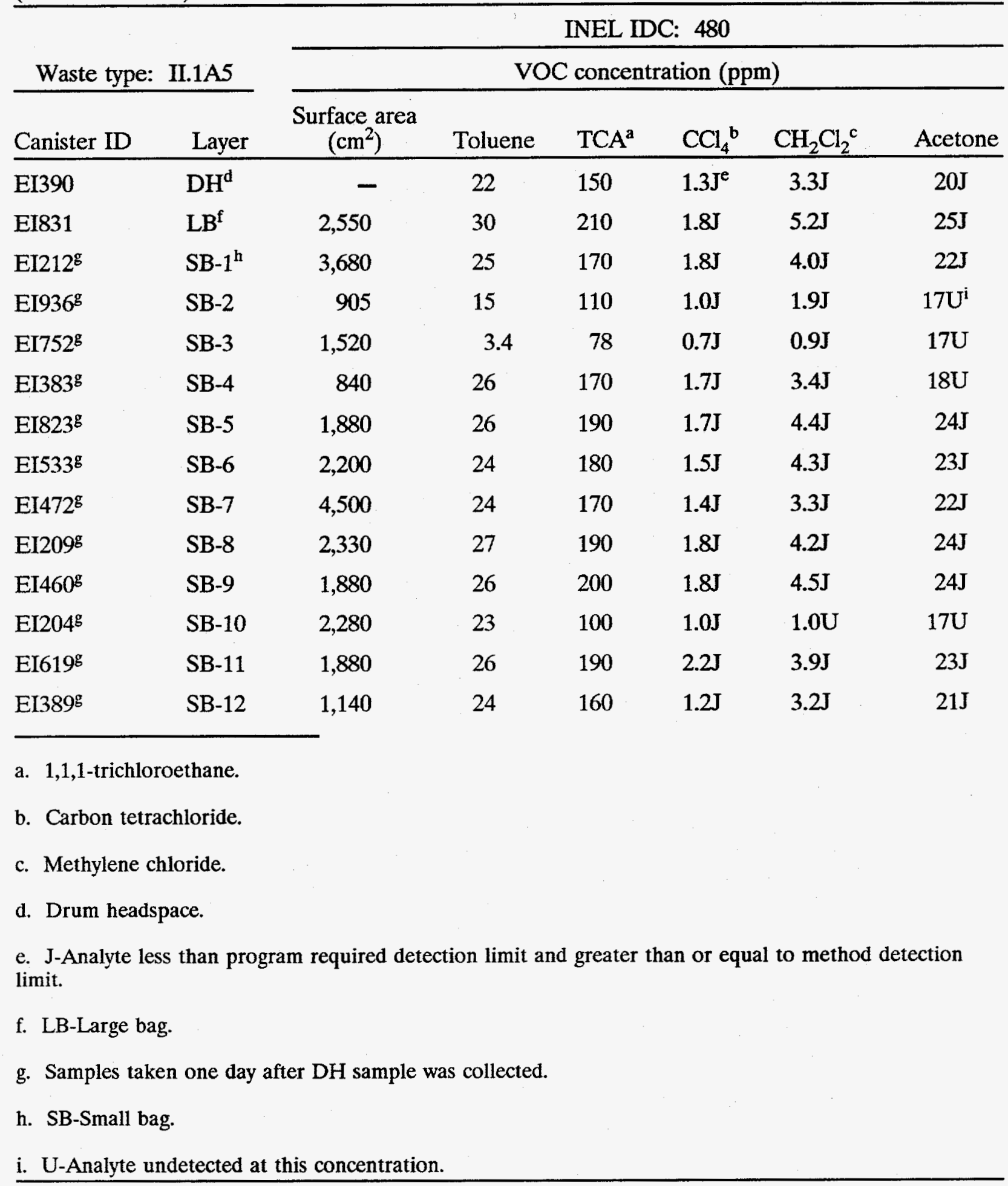


Table B-7. Measured VOC concentration and estimated bag surface area in vented waste drum (Drum ID 21952).

INEL IDC: 480

Waste type: II.1A5

VOC concentration

\begin{tabular}{|c|c|c|c|c|c|}
\hline Canister ID & Layer & $\begin{array}{c}\text { Surface area } \\
\left(\mathrm{cm}^{2}\right)\end{array}$ & Toluene & $\mathrm{TCA}^{\mathrm{a}}$ & $\mathrm{CCl}_{4}{ }^{\mathrm{b}}$ \\
\hline EI084 & $\mathrm{DH}^{\mathrm{c}}$ & - & 8.8 & 100 & $0.7 \mathrm{~J}^{\mathrm{d}}$ \\
\hline EI247 & DH-D & - & 7.4 & 97 & $0.8 \mathrm{~J}$ \\
\hline EI489g & $\mathrm{LB}^{\mathrm{f}}$ & 2,550 & 6.3 & 49 & $0.4 \mathrm{~J}$ \\
\hline $\mathrm{EI} 236^{\mathrm{g}, \mathrm{h}}$ & $\mathbf{S B}^{\mathbf{i}}$ & 8,320 & 8.9 & 100 & $1.2 \mathrm{~J}$ \\
\hline
\end{tabular}
a. 1,1,1-trichloroethane.
b. Carbon tetrachloride.
c. Drum headspace.

d. J-Analyte less than program required detection limit and greater than or equal to method detection limit.

e. D-Duplicate.

f. LB-Large bag.

g. Sample taken one day after DH sample was collected.

h. SB-Small bag. 
Table B-8. Measured VOC concentration and estimated surface area in vented waste drum (Drum ID 24214).

INEL IDC: 336

VOC concentration

Waste type: III.1A4 (ppm)

\begin{tabular}{|c|c|c|c|c|c|c|c|c|}
\hline Canister ID & Layer & $\begin{array}{l}\text { Surface area } \\
\qquad\left(\mathrm{cm}^{2}\right)\end{array}$ & Toluene & Xylene $^{a}$ & $\mathrm{TCA}^{\mathrm{b}}$ & $\mathrm{CCl}_{4}{ }^{\mathrm{c}}$ & $\mathrm{TCE}^{\mathrm{d}}$ & $\mathrm{CH}_{2} \mathrm{Cl}_{2}{ }^{\mathrm{e}}$ \\
\hline EI768 & $\mathrm{DH}^{\mathrm{f}}$ & - & 7.8 & 21 & 98 & $0.5 \mathrm{U}^{\mathrm{g}}$ & $2.4 \mathrm{~J}^{\mathrm{h}}$ & 11 \\
\hline EI751 & $\mathrm{LB}^{\mathrm{i}}$ & 2,550 & 9.6 & 27 & 130 & $0.8 \mathrm{~J}$ & $3.2 \mathrm{~J}$ & 14 \\
\hline EI819 & $S B-1^{j}$ & 4,160 & 7.7J & 19 & 120 & $4.3 \mathrm{~J}$ & $4.5 \mathrm{~J}$ & 12 \\
\hline EI856 & SB-2 & 5,380 & 9.0 & 24 & 130 & $4.5 \mathrm{~J}$ & 4.9J & 13 \\
\hline EI858 & SB-3 & 7,940 & 9.7 & 26 & 130 & $0.7 \mathrm{U}$ & $3.0 \mathrm{~J}$ & 13 \\
\hline
\end{tabular}

a. m-,p-xylene.

b. 1,1,1-trichloroethane.

c. Carbon tetrachloride.

d. Trichloroethylene.

e. Methylene chloride.

f. Drum headspace.

g. U-Analyte undetected at this concentration.

h. J-Analyte less than program required detection limit and greater than or equal to method detection limit.

i. LB-Large bag.

j. SB-Small bag. 
Table B-9. Measured VOC concentration and estimated surface area in vented waste drum (Drum ID 32529).

INEL IDC: 336

\begin{tabular}{|c|c|c|c|c|c|c|c|}
\hline \multirow{2}{*}{\multicolumn{2}{|c|}{ Waste type: III.1A4 }} & \multicolumn{6}{|c|}{ INEL IDC: 336} \\
\hline & & \multicolumn{6}{|c|}{$\begin{array}{l}\text { VOC concentration } \\
\qquad(\mathrm{ppm})\end{array}$} \\
\hline Canister ID & Layer & $\begin{array}{l}\text { Surface area } \\
\left(\mathrm{cm}^{2}\right)\end{array}$ & Toluene & $\mathrm{TCA}^{\mathrm{a}}$ & $\mathrm{CCl}_{4}{ }^{\mathrm{b}}$ & $\mathrm{TCE}^{\mathrm{c}}$ & $\mathrm{CH}_{2} \mathrm{Cl}_{2}{ }^{\mathrm{d}}$ \\
\hline EI769 & $\mathrm{DH}^{\mathrm{e}}$ & - & 39 & 250 & $1.4 \mathrm{U}^{\mathrm{f}}$ & $1.3 \mathrm{U}$ & 35 \\
\hline EI863 & $\mathrm{DH}-\mathrm{D}^{\mathrm{g}}$ & - & 34 & 220 & - & - & 32 \\
\hline EI428 & $\mathrm{LB}^{\mathrm{h}}$ & 2,550 & 14 & 58 & - & - & 7 \\
\hline EI585 & SB-1 ${ }^{\mathrm{i}}$ & 4,000 & 38 & 260 & - & - & 31 \\
\hline $\mathrm{EI} 243$ & SB-2 & 3,270 & 44 & 310 & - & - & 36 \\
\hline EI485 & SB-3 & 2,570 & 42 & 330 & - & - & 39 \\
\hline EI860 & SB-4 & 3,860 & 17 & 93 & $3.0 \mathrm{~J}^{\mathrm{j}}$ & $1.5 \mathrm{~J}$ & 11 \\
\hline
\end{tabular}
a. 1,1,1-trichloroethane.
b. Carbon tetrachloride.
c. Trichloroethylene.
d. Methylene chloride.
e. Drum headspace.

f. U-Analyte undetected at this concentration.

g. D-Duplicate.

h. LB-Large bag.

i. SB-Small bag.

j. J-Analyte less than program required detection limit and greater than or equal to method detection limit. 
Table B-10. Measured VOC concentration and estimated surface area in vented waste drum (Drum ID 10216).

INEL IDC: 338

\section{VOC concentration}

Waste type: III.1A4 (ppm)

\begin{tabular}{llccccccc}
\cline { 3 - 8 } Canister ID & Layer & $\begin{array}{c}\text { Surface } \\
\text { area }\left(\mathrm{cm}^{2}\right)\end{array}$ & Toluene & $\mathrm{TCA}^{\mathrm{a}}$ & $\mathrm{CCl}_{4}{ }^{\mathrm{b}}$ & $\mathrm{TCE}^{\mathrm{c}}$ & $\mathrm{C}_{2} \mathrm{Cl}_{4}{ }^{\mathrm{d}}$ & $\mathrm{C}_{2} \mathrm{H}_{2} \mathrm{Cl}_{2}{ }^{\mathrm{e}}$ \\
\hline EI468 & $\mathrm{DH}^{\mathrm{f}}$ & - & $0.3 \mathrm{U}^{\mathrm{g}}$ & 11 & $0.5 \mathrm{~J}^{\mathrm{h}}$ & 39 & $0.5 \mathrm{~J}$ & $1.2 \mathrm{~J}$ \\
EI177 & $\mathrm{LB}^{\mathrm{i}}$ & 2,550 & $4.8 \mathrm{U}$ & 270 & $14 \mathrm{~J}$ & 810 & $11 \mathrm{~J}$ & $31 \mathrm{~J}$ \\
EI274 & $\mathrm{SB}^{\mathrm{j}}$ & $-{ }^{\mathrm{j}}$ & - & 240 & $12 \mathrm{~J}$ & 740 & $10 \mathrm{~J}$ & $28 \mathrm{~J}$ \\
EI476 & SB-2 & 5,800 & $3.0 \mathrm{~J}$ & 220 & $11 \mathrm{~J}$ & $710 \mathrm{D}^{1}$ & $8.9 \mathrm{~J}$ & 25 \\
EI253 & SB-3 & 5,570 & - & 240 & $12 \mathrm{~J}$ & 690 & $9.6 \mathrm{~J}$ & $28 \mathrm{~J}$ \\
EI972 & SB-4 & 5,950 & $3.0 \mathrm{~J}$ & 220 & $12 \mathrm{~J}$ & $600 \mathrm{D}$ & $8.8 \mathrm{~J}$ & 23 \\
EI423 & SB-5 & 2,780 & - & 290 & $14 \mathrm{~J}$ & 880 & $12 \mathrm{~J}$ & $33 \mathrm{~J}$ \\
EI421 & SB-6 & 1,930 & - & 280 & $14 \mathrm{~J}$ & 840 & $12 \mathrm{~J}$ & $32 \mathrm{~J}$ \\
EI426 & SB-7 & 1,540 & - & 280 & $13 \mathrm{~J}$ & 790 & $12 \mathrm{~J}$ & $29 \mathrm{~J}$
\end{tabular}

a. 1,1,1-trichloroethane.

b. Carbon tetrachloride.

c. Trichloroethylene.

d. Tetrachloroethylene.

e. 1,1-Dichloroethene

f. Drum headspace.

g. U-Analyte undetected at this concentration.

h. J-Analyte less than program required detection limit and greater than or equal to method detection limit.

i. LB-Large bag.

j. SB-Small bag.

k. Unable to determine.

1. D-Duplicate. 
Table B-11. Measured VOC concentration and estimated bag surface area in vented waste drum (Drum ID 23901).

\begin{tabular}{|c|c|c|c|c|c|}
\hline & & & INEL IDC & & \\
\hline Waste ty & & & $\begin{array}{r}\text { OC conce } \\
(\mathrm{ppm}\end{array}$ & & \\
\hline Canister ID & Layer & $\begin{array}{l}\text { Surface area } \\
\left(\mathrm{cm}^{2}\right)\end{array}$ & Toluene & $\mathrm{TCA}^{\mathrm{a}}$ & $\mathrm{TCE}^{\mathrm{b}}$ \\
\hline EI205 & $\mathrm{DH}^{\mathrm{c}}$ & - & $9.2 \mathrm{~J}^{\mathrm{d}}$ & 340 & 93 \\
\hline EI181 & $\mathrm{LB}^{\mathrm{e}}$ & 2,550 & $9.8 \mathrm{~J}$ & 280 & 88 \\
\hline a. 1,1,1-trichl & & & & & \\
\hline b. Trichloroet & & & & & \\
\hline c. Drum head & & & & & \\
\hline $\begin{array}{l}\text { d. J-Analyte } 1 \\
\text { limit. }\end{array}$ & ogram I & detection limit & ter than or & metho & \\
\hline e. LB-Large $b$ & & & & & \\
\hline
\end{tabular}


Table B-12. Measured VOC concentration and estimated bag surface area in vented waste drum (Drum ID 24786).

INEL IDC: 480

Waste type: II.1A5

VOC concentration

(ppm)

\begin{tabular}{|c|c|c|c|c|c|c|}
\hline Canister ID & Layer & $\begin{array}{l}\text { Surface area } \\
\left(\mathrm{cm}^{2}\right)\end{array}$ & Toluene & $\mathrm{TCA}^{\mathrm{a}}$ & $\mathrm{CH}_{2} \mathrm{Cl}_{2}{ }^{\mathrm{b}}$ & $\mathrm{CHCl}_{3}{ }^{\mathrm{c}}$ \\
\hline EI388 & $\mathrm{DH}^{\mathrm{d}}$ & - & $4.6 \mathrm{~J}^{\mathrm{e}}$ & 63 & $4.6 \mathrm{~J}$ & $0.5 \mathrm{~J}$ \\
\hline EI432 & $\mathrm{LB}^{\mathrm{f}}$ & 2,550 & $7.1 \mathrm{~J}$ & 120 & 10 & $1.1 \mathrm{~J}$ \\
\hline $\mathrm{EI} 222$ & SB-1 ${ }^{g}$ & 1,400 & 2.9 & 14 & 1.2 & $0.2 \mathrm{~J}$ \\
\hline EI456 & SB-2 & 1,325 & 1.8 & 14 & 1.2 & $0.2 \mathrm{~J}$ \\
\hline
\end{tabular}

a. 1,1,1-trichloroethane.

b. Methylene chloride.

c. Chloroform.

d. Drum headspace.

e. J-Analyte less than program required detection limit and greater than or equal to method detection limit.

f. LB-Large bag.

g. SB-Small bag. 
Table B-13. Measured VOC concentration and estimated bag surface area in vented waste drum (Drum ID 10663).

\begin{tabular}{|c|c|c|c|c|c|}
\hline \multirow{2}{*}{\multicolumn{2}{|c|}{ Waste type: III.1A5 }} & \multicolumn{4}{|c|}{ INEL IDC: 337} \\
\hline & & \multicolumn{4}{|c|}{$\begin{array}{l}\text { VOC concentration } \\
(\mathrm{ppm})\end{array}$} \\
\hline Canister ID & Layer & $\begin{array}{l}\text { Surface area } \\
\left(\mathrm{cm}^{2}\right)\end{array}$ & Toluene & $\mathrm{TCA}^{\mathrm{a}}$ & $\mathrm{TCE}^{\mathrm{b}}$ \\
\hline $\mathrm{EI} 278$ & $\mathrm{DH}^{\mathrm{c}}$ & - & $5.4 J^{\mathrm{d}}$ & 140 & 210 \\
\hline $\mathrm{EI} 232$ & $\mathrm{LB}^{\mathrm{e}}$ & 2,550 & $5.8 \mathrm{~J}$ & 150 & 220 \\
\hline \multicolumn{6}{|c|}{ a. 1,1,1-trichloroethane. } \\
\hline \multicolumn{6}{|c|}{ b. Trichloroethylene. } \\
\hline \multicolumn{6}{|c|}{ c. Drum headspace. } \\
\hline \multicolumn{6}{|c|}{$\begin{array}{l}\text { d. J-Analyte less than program required detection limit and greater than or equal to method detection } \\
\text { limit. }\end{array}$} \\
\hline e. LB-Large & & & & & \\
\hline
\end{tabular}


Table B-14. Measured VOC concentration and estimated bag surface area in vented waste drum (Drum ID 07170).

INEL IDC: 337

Waste type: III.1A5

VOC concentration

(ppm)

\begin{tabular}{llcccccc}
\cline { 5 - 7 } Canister ID & Layer & $\begin{array}{c}\text { Surface area } \\
\left(\mathrm{cm}^{2}\right)\end{array}$ & Toluene & $\mathrm{TCA}^{\mathrm{a}}$ & $\mathrm{TCE}^{\mathrm{b}}$ & Acetone & $\mathrm{C}_{2} \mathrm{H}_{4} \mathrm{Cl}_{2}{ }^{\mathrm{c}}$ \\
\hline EI273 & $\mathrm{DH}^{\mathrm{d}}$ & - & $3.6 \mathrm{~J}^{\mathrm{e}}$ & 150 & 240 & 62 & 27 \\
EI385 & DH-D & - & $3.3 \mathrm{~J}$ & 140 & 240 & 62 & 27 \\
EI259 & LB $^{\mathrm{f}}$ & 2,550 & $7.2 \mathrm{~J}$ & 310 & 490 & 110 & 60
\end{tabular}
a. 1,1,1-trichloroethane.
b. Trichloroethylene.
c. 1,1-dichloroethane.
d. Drum headspace.

e. J-Analyte less than program required detection limit and greater than or equal to method detection limit.

f. D-Duplicate.

g. LB-Large bag. 
Table B-15. Measured VOC concentration and estimated bag surface area in vented waste drum (Drum ID 08878).

\begin{tabular}{|c|c|c|c|c|c|}
\hline \multirow{2}{*}{\multicolumn{2}{|c|}{ Waste type: II.1A5 }} & \multicolumn{4}{|c|}{ INEL IDC: 480} \\
\hline & & \multicolumn{4}{|c|}{$\begin{array}{l}\text { VOC concentration } \\
(\mathrm{ppm})\end{array}$} \\
\hline Canister ID & Layer & $\begin{array}{l}\text { Surface area } \\
\left(\mathrm{cm}^{2}\right)\end{array}$ & $\mathrm{TCA}^{\mathrm{a}}$ & $\mathrm{CCl}_{4}{ }^{\mathrm{b}}$ & $\mathrm{CHCl}_{3}{ }^{\mathrm{c}}$ \\
\hline EI754 & $\mathrm{DH}^{\mathrm{d}}$ & - & 1,400 & $8.8 U^{e}$ & $9.1 \mathrm{U}$ \\
\hline EI773 & $\mathrm{DH}-\mathrm{D}^{\mathfrak{f}}$ & - & 1,400 & - & - \\
\hline EI429 & LB-g & 2,550 & 170 & - & - \\
\hline EI767 & SB-1 ${ }^{h}$ & 2,700 & 77 & - & - \\
\hline EI616 & SB-2 & 4,470 & 1,900 & $14 J^{i}$ & - \\
\hline EI522 & SB-3 & 2,170 & 1,900 & - & - \\
\hline EI774 & SB-4 & 3,030 & 1,700 & - & - \\
\hline EI382 & SB-5 & 1,530 & 6,200 & - & - \\
\hline EI082 & SB-6 & 1,530 & 4,400 & - & $24 \mathrm{~J}$ \\
\hline EI459 & SB-7 & 1,530 & 1,900 & - & - \\
\hline EI051 & SB-8 & 1,530 & 2,500 & $31 \mathrm{~J}$ & $25 \mathrm{~J}$ \\
\hline \multicolumn{6}{|c|}{ a. 1,1,1-trichloroethane. } \\
\hline \multicolumn{6}{|c|}{ b. Carbon tetrachloride. } \\
\hline \multicolumn{6}{|c|}{ c. Chloroform. } \\
\hline \multicolumn{6}{|c|}{ d. Drum headspace. } \\
\hline \multicolumn{6}{|c|}{ e. U-Analyte undetected at this concentration. } \\
\hline \multicolumn{6}{|c|}{ f. D-duplicate. } \\
\hline \multicolumn{6}{|c|}{ g. LB-Large bag. } \\
\hline \multicolumn{6}{|c|}{ h. SB-Small bag. } \\
\hline $\begin{array}{l}\text { i. J-Analyte I } \\
\text { limit. }\end{array}$ & rogram $\mathrm{re}$ & tection limit a & er than 0 & 1 to metho & tion \\
\hline
\end{tabular}


Table B-16. Measured VOC concentration and estimated bag surface area in vented waste drum (Drum ID 22249).

INEL IDC: 480

Waste type: II.1A5

VOC concentration

\begin{tabular}{|c|c|c|c|c|c|c|}
\hline Canister ID & Layer & $\begin{array}{l}\text { Surface area } \\
\qquad\left(\mathrm{cm}^{2}\right)\end{array}$ & Toluene & $\mathrm{TCA}^{\mathrm{a}}$ & $\mathrm{MeOH}^{\mathrm{b}}$ & Acetone \\
\hline EI457 & $\mathrm{DH}^{\mathrm{c}}$ & - & $12 J^{d}$ & 1,500 & $17 \mathrm{U}^{\mathrm{e}}$ & $17 \mathrm{U}$ \\
\hline EI592 & $\mathrm{LB}^{\mathrm{f}}$ & 2,550 & $11 U$ & 1,100 & 一 & $20 \mathrm{~J}$ \\
\hline EI530 & $\mathrm{LB}-\mathrm{D}^{\mathrm{g}}$ & - & $11 \mathrm{~J}$ & 1,300 & - & $22 J$ \\
\hline EI532 & SB-1 $1^{\mathrm{h}}$ & 2,820 & $13 \mathrm{~J}$ & 1,300 & $22 J$ & $27 \mathrm{~J}$ \\
\hline EI772 & SB-2 & 1,840 & $12 \mathrm{~J}$ & 1,400 & - & $22 \mathrm{~J}$ \\
\hline EI620 & SB-3 & 1,800 & $14 \mathrm{~J}$ & 1,500 & - & $22 J$ \\
\hline EI465 & SB-4 & 4,030 & $11 \mathrm{U}$ & 1,200 & 一 & $22 J$ \\
\hline EI782 & SB-5 & 2,300 & $11 \mathrm{U}$ & 1,300 & 一 & $21 \mathrm{~J}$ \\
\hline \multicolumn{7}{|c|}{ a. 1,1,1-trichloroethane. } \\
\hline \multicolumn{7}{|l|}{ b. Methanol. } \\
\hline \multicolumn{7}{|c|}{ c. Drum headspace. } \\
\hline \multicolumn{7}{|c|}{$\begin{array}{l}\text { d. J-Analyte less than program required detection limit and greater than or equal to method detection } \\
\text { limit. }\end{array}$} \\
\hline \multicolumn{7}{|c|}{ e. U-Analyte undetected at this concentration. } \\
\hline \multicolumn{7}{|c|}{ f. LB-Large bag. } \\
\hline \multicolumn{7}{|c|}{ g. D-Duplicate. } \\
\hline h. SB-Small & & & & & & \\
\hline
\end{tabular}


Table B-17. Measured VOC concentration and estimated bag surface area in vented waste drum (Drum ID 11433).

INEL IDC: 330

\begin{tabular}{|c|c|c|c|c|c|c|}
\hline \multirow{2}{*}{$\begin{array}{l}\text { Waste type: } \\
\text { Canister ID }\end{array}$} & \multirow{2}{*}{$\begin{array}{l}\text { III.1A5 } \\
\text { Layer }\end{array}$} & \multicolumn{5}{|c|}{$\begin{array}{l}\text { VOC concentration } \\
\qquad(\mathrm{ppm})\end{array}$} \\
\hline & & $\begin{array}{l}\text { Surface area } \\
\qquad\left(\mathrm{cm}^{2}\right)\end{array}$ & Toluene & $\mathrm{TCA}^{\mathrm{a}}$ & $\mathrm{CC}_{4}{ }^{\mathrm{b}}$ & $\mathrm{TCE}^{\mathrm{C}}$ \\
\hline EI195 & $\mathrm{DH}^{\mathrm{d}}$ & - & $9.3 \mathrm{DJ}^{\mathrm{e}, \mathrm{f}}$ & $200 \mathrm{D}$ & $2.0 \mathrm{DJ}$ & $330 \mathrm{D}$ \\
\hline EI185 & DH-Dup ${ }^{g}$ & - & $1.9 \mathrm{~J}$ & 40 & $0.5 \mathrm{DJ}$ & 68 \\
\hline EI003 & $\mathrm{LB}^{\mathrm{h}}$ & 2,550 & $10 \mathrm{DJ}$ & $220 \mathrm{D}$ & $2.5 \mathrm{DJ}$ & $370 \mathrm{D}$ \\
\hline $\mathrm{EI} 250^{\mathrm{i}}$ & $\mathrm{SB}-1^{\mathrm{j}}$ & 2,370 & $10 \mathrm{~J}$ & 210 & $2.0 \mathrm{~J}$ & 340 \\
\hline EI828 ${ }^{i}$ & SB-2 & 6,360 & $9.7 \mathrm{~J}$ & 210 & $2.2 \mathrm{~J}$ & 350 \\
\hline $\mathrm{EI} 211^{\mathrm{i}}$ & SB-2 & - & $10 \mathrm{~J}$ & 200 & $2.0 \mathrm{~J}$ & 350 \\
\hline $\mathrm{EI} 471^{\mathrm{i}}$ & SB-3 & 4,920 & $7.8 \mathrm{U}$ & 150 & $1.5 \mathrm{~J}$ & 250 \\
\hline \multicolumn{7}{|c|}{ a. 1,1,1-trichloroethane. } \\
\hline \multicolumn{7}{|c|}{ b. Carbon tetrachloride. } \\
\hline \multicolumn{7}{|l|}{ c. Trichloroethylene } \\
\hline \multicolumn{7}{|l|}{ d. Drum headspace. } \\
\hline \multicolumn{7}{|l|}{ e. D-Dilution. } \\
\hline \multicolumn{7}{|c|}{ f. J-Analyte less than program required detection limit and greater than or equal to method detection limit. } \\
\hline \multicolumn{7}{|l|}{ g. Dup-Duplicate. } \\
\hline \multicolumn{7}{|l|}{ h. LB-Large bag. } \\
\hline \multicolumn{7}{|c|}{ i. Sample taken one day after DH sample was collected. } \\
\hline j. SB-Small bag. & & & & & & \\
\hline
\end{tabular}

